\title{
Efficient and economical degradation of minocycline by natural bornite-activated hydrogen peroxide and persulfate: kinetics and mechanisms
}

\section{Taikang Yuan}

Xi'an University of Architecture and Technology

Xu-dong Wang ( $\triangle$ xudongw7904@126.com)

Xi'an University of Architecture and Technology https://orcid.org/0000-0003-1710-7421

\section{Xiaochen Zhao}

Xi'an University of Architecture and Technology

Tingting Liu

Xi'an Polytechnic University

Hongmin Zhang

Xi'an University of Architecture and Technology

\section{Yongtao Lv}

Xi'an University of Architecture and Technology

Lei Wang

Xi'an University of Architecture and Technology

\section{Research Article}

Keywords: Minocycline, Hydroxyl radical, Sulfate radical, Degradation pathway, Toxicity evaluation, Bimetallic effect

Posted Date: April 19th, 2021

DOI: https://doi.org/10.21203/rs.3.rs-298736/v1

License: (1) (i) This work is licensed under a Creative Commons Attribution 4.0 International License. Read Full License

Version of Record: A version of this preprint was published at Environmental Science and Pollution Research on July 22nd, 2021. See the published version at https://doi.org/10.1007/s11356-021-15500-2. 


\section{Abstract}

Natural bornite (NBo), a sulfide mineral of copper and iron, is one of the main mineral raw materials for copper extraction. In this study, NBo-activated hydrogen peroxide $\left(\mathrm{H}_{2} \mathrm{O}_{2}\right)$ and persulfate processes (PS) for the degradation of minocycline (MNC) in aqueous solution were systemically investigated and compared. The $\mathrm{MNC}$ removal rates with the $\mathrm{NBo} / \mathrm{PS}$ and $\mathrm{NBo} / \mathrm{H}_{2} \mathrm{O}_{2}$ processes were $86.40 \%$ and $87.50 \%$, respectively. The mineralization rate of NBo/PS (33.96\%) was higher than that of $\mathrm{NBo} / \mathrm{H}_{2} \mathrm{O}_{2}(29.94 \%)$ after reaction for $180 \mathrm{~min}$. The effects of oxidant and activator dosage, $\mathrm{pH}, \mathrm{common}$ inorganic anions (i.e., $\mathrm{Cl}^{-}, \mathrm{NO}_{3}{ }^{-}$, and $\mathrm{HCO}_{3}{ }^{-}$), and water composition on $\mathrm{MNC}$ degradation were systematically evaluated. In addition, the degradation of MNC in natural water matrix and toxicity evaluation were also studied to better evaluate the feasibility of practical application of those two processes. The results of free radical quenching experiments and electron paramagnetic resonance spectroscopy (EPR) showed that $\mathrm{HO}$. was the main activated species in the $\mathrm{NBo} / \mathrm{H}_{2} \mathrm{O}_{2}$ system, while $\mathrm{SO}_{4}{ }^{-{ }^{-}}$and $\mathrm{HO}$. were the main activated species in the NBo/PS system. The degradation of MNC in the NBo/PS system was achieved through electron transfer, while the degradation of $\mathrm{MNC}$ in the $\mathrm{NBo} / \mathrm{H}_{2} \mathrm{O}_{2}$ system was mainly achieved through free radical addition. The degradation pathway mainly included deamidation reactions, $\mathrm{C}-\mathrm{C}$ bond breakage and hydroxylation. Reusability of NBo showed that NBo was considerably stable in activating PS and $\mathrm{H}_{2} \mathrm{O}_{2}$ for degradation of MNC, which was cost-effective activator. This work provides a new perspective on the degradation mechanism of pollutants by Fe-Cu bimetallic sulfide activation of PS and $\mathrm{H}_{2} \mathrm{O}_{2}$.

\section{Introduction}

Due to the rapid development of the pharmaceutical field, the discharge of antibiotic-contaminated medical wastewater has increased significantly (Qu et al. 2020; Kang et al. 2016). As an emerging pollutant, the impact of this discharge on ecosystems has received extensive attention. Minocycline (MNC) is a broad-spectrum antibacterial tetracycline antibioticwhich has been frequently detected in water bodies with increasing concentrations in recent year. Since MNC has a variety of potential toxicities to organisms (such as liver and kidney damage, bacterial flora, and allergic reactions, etc.), its health risks to the environment have received considerable attention (Nowak et al. 2012; Maavia et al. 2019).

The emerging pollutants are difficult to be removed in the conventional sewage treatment plants (Rodriguez et al. 2011, 2017; Mantzavinos et al. 2017). Therefore, it is of great significance to develop low-cost and environmental-friendly method to effectively remove it from wastewater. Recently, advanced oxidation processes (AOPs) based on activate PS and $\mathrm{H}_{2} \mathrm{O}_{2}$ has proven to be a promising method to remove refractory pollutants in the aquatic environment (Fan et al. 2021; Huang et al. 2020). Sulfate radicals $\left(\mathrm{SO}_{4}{ }^{-}\right)$and hydroxyl radicals $(\mathrm{HO} \cdot)$ have high standard reduction potentials, namely $\mathrm{SO}_{4}{ }^{-{ }^{-}}\left(\mathrm{E}^{0}=\right.$ 2.5-3.1 V) and $\mathrm{HO} \cdot\left(\mathrm{E}^{0}=1.9-2.7 \mathrm{~V}\right)$, so it has strong oxidation ability (Cashman et al. 2019). PS and $\mathrm{H}_{2} \mathrm{O}_{2}$ can be activated in many ways to generate $\mathrm{SO}_{4}{ }^{-{ }^{-}}$and $\mathrm{HO}$, such as UV (Yang et al. 2010), heat (Lv et al. 
2020), alkali (Giannakis et al. 2021), transition metals (Saien et al. 2011) and nano carbon materials (Xing et al. 2020), etc.

Among these activation methods, transition metal activation, especially $\mathrm{Fe}^{2+}$ activation, has been relatively extensively studied becaues of its relative non-toxic, high efficiency and low-cost advantages, as described in Eqs. ((1), (2)) (Niu et al. 2012; Song et al. 2019). However, shortcomings of Fe $\mathrm{F}^{2+} / \mathrm{PS}$ and the $\mathrm{Fe}^{2+} / \mathrm{H}_{2} \mathrm{O}_{2}$ processes such as fast consumption of $\mathrm{Fe}^{2+}$ and generation of iron sludge greatly limits the degradation effects on pollutants (Cai et al. 2014). To solve these problems, the methods such as adding complexing agents (e.g., citric acid, EDTA) to the $\mathrm{Fe}^{2+} / \mathrm{PS}$ and $\mathrm{Fe}^{2+} / \mathrm{H}_{2} \mathrm{O}_{2}$ processes (Dulova et al. 2017), heterogeneous catalysts like zero-valent iron (Mossmann et al. 2019) synthetic transition metal oxides (e.g., $\mathrm{CuFe}_{2} \mathrm{O}_{4}, \mathrm{Fe}_{2} \mathrm{O}_{3} @ \mathrm{CuO}_{2}$ and $\mathrm{Fe}_{4} @ S W N T$ ) were developed (Karimipourfard et al. 2019). Although these artificially synthesized catalysts have good activation performance for $\mathrm{PS}$ or $\mathrm{H}_{2} \mathrm{O}_{2}$, it has the disadvantages such as complicated processes, high costs and being difficult to recycle. At the same time, the dosage ratio of the complexing agent should be strictly controlled, which limits the practical application (Dulova et al. 2017).

$\mathrm{H}_{2} \mathrm{O}_{2}+\mathrm{Fe}^{2+}\left(\mathrm{Cu}^{+}\right) \rightarrow \mathrm{HO} \cdot \mathrm{HO}^{-}+\mathrm{Fe}^{3+}\left(\mathrm{Cu}^{2+}\right)(1)$

$\mathrm{S}_{2} \mathrm{O}_{8}{ }^{2-}+\mathrm{Fe}^{2+}\left(\mathrm{Cu}^{+}\right) \rightarrow \mathrm{SO}_{4}{ }^{2-}+\mathrm{SO}_{4}{ }^{--}+\mathrm{Fe}^{3+}\left(\mathrm{Cu}^{2+}\right)$

So far, exploring the potential application of AOPs for the treatment of MNC is still in the early stage (LV and $\mathrm{Li}$ 2018). Previous studies showed that free radicals (e.g., $\mathrm{SO}_{4}{ }^{-{ }^{-}}, \mathrm{HO} \cdot$ ) were consumed by non-target water substrates, such as natural organic matters and inorganic anions, which greatly limited their application in practice (Lei et al. 2015; Jose et al. 2021). The degradation of antibiotics by AOPs was mainly achieved through the breaking of $\mathrm{C}-\mathrm{O}$ bonds and the cleavage of functional groups by the addition of free radicals (Liu et al. 2019). However, there are few studies on the degradation process (mechanisms and pathways) of tetracycline antibiotic MNC. To the best of our knowledge, this is the first study on MNC degradation by AOPs based on $\mathrm{SO}_{4}{ }^{-}$; ; the same time, natural bornite (NBo, $\mathrm{Cu}_{5} \mathrm{FeS}_{4}$ ) has not been reported as activator of $\mathrm{H}_{2} \mathrm{O}_{2}$. Therefore, the degradation of $\mathrm{MNC}$ induced by NBo/PS and $\mathrm{NBo} / \mathrm{H}_{2} \mathrm{O}_{2}$ processes is worthy of further study.

Natural bornite (NBo) is one of the main products of copper refining, and its proven reserves rank second in the world (Zhang et al. 2020). Previous studies showed that the formation of free radicals in heterogeneous processes based partly on PS and $\mathrm{H}_{2} \mathrm{O}_{2}$ depends on the dissolution of metal ions on the surface of the activator (Teel et al. 2011; Sabri et al. 2020). The reducible sulfur in minerals contributed to the conversion of $\mathrm{Fe}^{3+}\left(\mathrm{Cu}^{2+}\right)$ to $\mathrm{Fe}^{2+}\left(\mathrm{Cu}^{+}\right)$, which improved the degradation of pollutants. Coincidentally, the bimetallic effect between Fe and $\mathrm{Cu}$ was extensively studied in terms of the activation of PS and $\mathrm{H}_{2} \mathrm{O}_{2}$ (Torres-Blancas et al. 2017; Yao et al. 2017; Wang et al. 2018). Hence, in this study, NBo is used as activator to activate PS and $\mathrm{H}_{2} \mathrm{O}_{2}$ to eliminate MNC. 
This study conduct an in-depth and systematic study on the degradation of MNC in the NBo/PS and $\mathrm{NBo} / \mathrm{H}_{2} \mathrm{O}_{2}$ processes, respectively. The objectives of this study are (i) to explore the influence of various experimental parameters, such as the PS and $\mathrm{H}_{2} \mathrm{O}_{2}$ concentrations, NBo dosage, common inorganic anions (e.g., $\mathrm{Cl}^{-}, \mathrm{NO}_{3}{ }^{-}$, and $\mathrm{HCO}_{3}{ }^{-}$) and $\mathrm{pH}$ value; (ii) to determine the dominant activated ingredients involved in MNC processes; (iii) to evaluate the pathways and mechanisms of MNC degradation in both the $\mathrm{NBo} / \mathrm{PS}$ and $\mathrm{NBo} / \mathrm{H}_{2} \mathrm{O}_{2}$ processes; (iv) to identify the technical feasibility of both the NBo/PS and $\mathrm{NBo} / \mathrm{H}_{2} \mathrm{O}_{2}$ processes for MNC degradation in different natural waters; and (v) to evaluate the toxicity of MNC samples by acute toxicity tests. Finally, the reusability of the NBo activator was studied.

\section{Materials And Methods}

\subsection{Chemicals and materials}

Minocycline hydrochloride (MNC, 98\%) was purchased from Yuanye Biological Technology Co., Ltd. Sodium persulfate $\left(\mathrm{Na}_{2} \mathrm{~S}_{2} \mathrm{O}_{8}, 99 \%\right)$ and hydrogen peroxide $\left(\mathrm{H}_{2} \mathrm{O}_{2}, 30 \%\right)$ were purchased from Shanghai Aladdin Biochemical Technology Co., Ltd. 5,5-Dimethyl-1-pyrroline-N-oxide (DMPO, $\geq 98 \%$ ) was purchased from Sigma-Aldrich (St. Louis, MO, USA). Acetonitrile $\left(\mathrm{C}_{2} \mathrm{H}_{3} \mathrm{~N}, \mathrm{HPLC}\right)$, methanol $\left(\mathrm{CH}_{3} \mathrm{OH}, \mathrm{HPLC}\right)$, ethanol (EtOH, 95\%) and tertiary butanol (TBA, 98\%) were purchased from Tianjin Komiou Chemical Reagent Co., Ltd. High-purity bornite ore (NBo) was purchased from Hunan Geological Museum, Changsha, Hunan Province, China. After NBo was fully ground and sieved $(<180 \mu \mathrm{m})$, the resulting black powder was used as the activator for this experiment. Use Milli-Q water $(18.2 \mathrm{~m} \Omega \cdot \mathrm{cm}$, Millipore system) to prepare the solution.

\subsection{Experimental procedures}

All experiments were performed on a magnetic stirrer with constant temperature at $25 \pm 0.5^{\circ} \mathrm{C}$. During the experiment, the initial concentration of MNC was $10 \mathrm{mg} / \mathrm{L}$, which was significantly higher than its concentration in actual water. A certain dose of NBo was firstly introduced to the $100 \mathrm{ml}$ vial containing $10 \mathrm{mg} / \mathrm{L}$ aqueous solution of $\mathrm{MNC}$, after half an hour of adsorption-desorption equilibrium, added a certain volume of $\mathrm{PS} / \mathrm{H}_{2} \mathrm{O}_{2}$ to start the reaction. Before the reaction started, $0.01 \mathrm{M} \mathrm{H}_{2} \mathrm{SO}_{4}$ or $\mathrm{NaOH}$ were used to adjust the $\mathrm{pH}$ of the solution, and the $\mathrm{pH}$ was no longer adjusted during the degradation process. At a specific time, taked $2 \mathrm{~mL}$ water sample and immediately quenched it with $1 \mathrm{~mL} \mathrm{EtOH} \mathrm{(17.2M),} \mathrm{and}$ filtered by a $0.22 \mu \mathrm{m}$ membrane filter (Jinteng, Tianjin, China) to quantitatively analyze the remaining contaminants. All experiments were repeated at least three times to ensure repeatability.

The influence of $\mathrm{PS} / \mathrm{H}_{2} \mathrm{O}_{2}$ concentration $(0-1000 \mu \mathrm{M})$ and NBo dosage $(0-0.2 \mathrm{~g} / \mathrm{L})$ on the degradation of MNC were investigated at $\mathrm{pH}=4.5$ (unadjusted), respectively. At the same time, the effect of typical inorganic anions (i.e., $\mathrm{Cl}^{-}, \mathrm{NO}_{3}{ }^{-}$, and $\mathrm{HCO}_{3}{ }^{-}$) on $\mathrm{MNC}$ degradation in the water body was explored at $\mathrm{pH}=$ 4.5 as well. Under the condition of $\mathrm{pH} 2.5-9.5$, the influence of $\mathrm{pH}$ on $\mathrm{NBo} / \mathrm{PS}$ and $\mathrm{NBo} / \mathrm{H}_{2} \mathrm{O}_{2}$ oxidation processes were studied. It was worth mentioning that the $\mathrm{pH}$ adjustment must be carried out before addition of NBo to avoid the influence of oxidation of NBo and trace metal ions in the solution. To 
evaluate the reusability of NBo, the used NBo was suction filtered after 180 min reaction, the retained NBo powder was collected and washed with ultrapure water, and dried overnight in a vacuum drying oven at $60^{\circ} \mathrm{C}$ for the next use. This process repeated several times.

\subsection{Identification of MNC concentrations and MNC transformation products}

The concentration of MNC was analyzed by LC-2000 (JASCO, Japan). The separation column was a C-18 reverse chromatographic column, and the mobile phase was $0.2 \%$ phosphoric acid: acetonitrile $=12: 88$ (v: v). The flow rate was $1 \mathrm{ml} / \mathrm{min}$, and the column temperature was $25^{\circ} \mathrm{C}$. The injection volume was $50 \mu \mathrm{L}$, and the UV detection wavelength was $252 \mathrm{~nm}$.

As described above in Sect. 2.2, the samples were collected at specific time intervals and filtrated with $0.22 \mu \mathrm{m}$ filter for further analysis. The conversion products during the degradation of MNC were determined by I-Class-VION-IMS-Qtof (Waters, USA). The separation column was a Thermo Scientific HPLC Betasil C18 column (2.1 mm i.d. × $150 \mathrm{~mm}, 3.5 \mathrm{~mm}$ particles). The mobile phases were $0.1 \%$ formic acid and acetonitrile. The two mobile phases were proportioned by gradient elution within 6 minutes, the gradient table as showed in Table S2. The flow rate was $0.4 \mathrm{~mL} / \mathrm{min}$, the temperature of the column was $35^{\circ} \mathrm{C}$, and the injection volume was $5 \mu \mathrm{L}$. The sample temperature of the sample bin was kept at $10^{\circ} \mathrm{C}$. Mass spectrometry with an ESI source worked in the positive mode. The mass-to-charge ratio (m/z) acquisition range was 50 to 2000. For more detailed operating parameters of MS mode were shown in Table S3.

\subsection{Identification of dominant active species}

Free radical scavengers were added to the aqueous solution before the reaction started to capture the main free radicals in the $\mathrm{NBo} / \mathrm{PS}$ and $\mathrm{NBo} / \mathrm{H}_{2} \mathrm{O}_{2}$ processes. EtOH and TBA were used as target scavengers at a concentration of $50 \mathrm{mM}$ to capture $\mathrm{SO}_{4}{ }^{--}$and $\mathrm{HO} \cdot$, respectively. The remaining conditions were the same as the reaction conditions under the optimal activator and oxidant dosage.

5,5-Dimethyl-1-pyrroline-N-oxide (DMPO) could capture $\mathrm{SO}_{4}{ }^{--}$and $\mathrm{HO}$. At a specific time, quickly added $0.1 \mathrm{~mL}(100 \mathrm{mM})$ DMPO solution to $1 \mathrm{~mL}$ reaction solution, and shook for approximately 2 minutes. Then an electron paramagnetic resonance spectrometer (EPR, Bruker, Germany) was used to record the spectra of the radical adducts. Terephthalic acid (TA, $10 \mathrm{mg} / \mathrm{L}$ ) could react with hydroxyl radicals to form a stable fluorescent substance 2-hydroxyterephthalic acid (2-HTA). This substance could be used to quantitatively measure hydroxyl radicals under a fluorescence spectrophotometer (F-7000, Hitachi, Japan). The detection conditions were excitation wavelength of $315 \mathrm{~nm}$ and emission wavelengths of $250 \mathrm{~nm}$ and $425 \mathrm{~nm}$. The concentration of persulfate was determined by spectrophotometry.

\subsection{Characterization of the NBo powder}

X-ray fluorescence spectroscopy (XRF, ARLAdvant'XIntellipower3600) and X-ray electron spectroscopy (XPS, Thermo, Scientific K-Alpha) were used to analyze the element distribution on the surface of the NBo 
powder. The crystal phase of the NBo powder was analyzed using an X-ray diffractometer (XRD, Ultima IV, Japan). The mineralization rate of the solution was measured with a total organic carbon analyzer (TOC, Shimadzu, Japan).

\subsection{Acute toxicity tests}

The toxicity changes during MNC degradation were determinated by $V$. fischeri with bioluminescence instrument. The bacteria were resuscitated before toxicity test. $100 \mu \mathrm{L}$ of the resuscitated bacterial solution was mixed with $1 \mathrm{~mL}$ of aqueous solution evenly, and use CentroPRO LB962 bioluminescence detector (Berthold Technologies, Germany) to record the initial luminosity of each sample and the luminosity after $15 \mathrm{~min}$. It is worth nothing that the $\mathrm{NaCl}$ solution (2\%) was used as a negative control, and recorded its initial luminous intensity (Liu et al. 2019).

The toxicity of samples is expressed by luminescence inhibition rate, as described in Eq.

$I(\%)=\left(S_{0} * C_{f} S_{t}\right) /\left(S_{0} * C_{f}\right) * 100 \%(3)$

Where $S_{0}$ is the initial luminous intensity of the sample and $S_{t}$ is the luminous intensity of the sample mixed for $15 \mathrm{~min} . \mathrm{C}_{\mathrm{f}}$ is the ratio of the luminous intensity after the negative control for 15 minutes to the initial luminous intensity $\left(0.6 \leq \mathrm{C}_{\mathrm{f}} \leq 1.8\right)$. The change of toxicity is expressed by the percentage of luminescence inhibition rate of samples.

\section{Results And Discussion}

\subsection{Degradation kinetics of MNC 3.1.1 Effect of initial oxidant concentration}

As shown in Fig. 1a and b, the effect of different initial oxidant doses (i.e., PS and $\mathrm{H}_{2} \mathrm{O}_{2}$ ) on the degradation rates of MNC was investigated. Only $1.44 \%$ of MNC was degraded by addition of $0.15 \mathrm{~g} / \mathrm{L}$ NBo alone, indicated that the adsorption and degradation of MNC by NBo could be negligible. However, in the $\mathrm{NBo} / \mathrm{PS}$ and $\mathrm{NBo} / \mathrm{H}_{2} \mathrm{O}_{2}$ processes, the degradation rates of $\mathrm{MNC}$ increased to $86.40 \%$ and $87.50 \%$ after $180 \mathrm{~min}$ (when $\left[\mathrm{H}_{2} \mathrm{O}_{2}\right]_{0}=[\mathrm{PS}]_{0}=500 \mu \mathrm{M}$ ), indicated that PS and $\mathrm{H}_{2} \mathrm{O}_{2}$ were effectively oxidated by NBo, respectively. Obviously, when the concentration of oxidants (i.e., PS and $\mathrm{H}_{2} \mathrm{O}_{2}$ ) increased from $25 \mu \mathrm{M}$ to $500 \mu \mathrm{M}$, the degradation rates of MNC gradually increased, indicating that a higher concentration of oxidant is needed to achieve a better degradation rates in the target time. When the concentration of $\mathrm{H}_{2} \mathrm{O}_{2}$ increased from $500 \mu \mathrm{M}$ to $1000 \mu \mathrm{M}$, the degradation rates of MNC only increased by $3.63 \%$ after $180 \mathrm{~min}$, and there was no obvious change in the degradation rates of $\mathrm{MNC}$, because the ion (e.g., $\left.\mathrm{Fe}^{2+}, \mathrm{Cu}^{+}\right)$ leaching from solution was insufficient, this will be limited the degradation rate of MNC (Eqs. (1)) (Song et al. 2019; Bi et al. 2020). It was worth noting that when the PS concentration increased from $500 \mu \mathrm{M}$ to $1000 \mu \mathrm{M}$, the degradation rates of MNC decreased slightly after 180 min of reaction. This phenomenon 
was attributed to the excessive PS reacted with $\mathrm{SO}_{4}{ }^{--}$to produce $\mathrm{S}_{2} \mathrm{O}_{8}{ }^{-{ }^{-}}$with low activation activity, and an insufficient concentration of metal ions limited the production speed of $\mathrm{SO}_{4}{ }^{--}$, while the $\mathrm{S}_{\mathrm{n}}{ }^{2-}$ in the solution was partially consumed by $\mathrm{S}_{2} \mathrm{O}_{8}{ }^{2-}$, which hindered the continuous chain reaction (Eqs. (3)-(5)) (Wang et al. 2019). Although $\mathrm{H}_{2} \mathrm{O}_{2}$ could react with the $\mathrm{HO}$ - formed in the solution to produce $\mathrm{HO}_{2}{ }_{2}$ with weaker activation activity (Eq. (6)), it does not affect the chain reaction in this process (Basiri et al. 2018). In short, in these two advanced oxidation processes (AOPs), considering the appropriate removal effect and cost-effectiveness, the optimal oxidant dosage was taken as $\left[\mathrm{H}_{2} \mathrm{O}_{2}\right]_{0}=[\mathrm{PS}]_{0}=500 \mu \mathrm{M}$.

$\mathrm{S}_{2} \mathrm{O}_{8}{ }^{2-}+\mathrm{SO}_{4}{ }^{--} \rightarrow \mathrm{SO}_{4}{ }^{2-}+\mathrm{S}_{2} \mathrm{O}_{8}{ }^{--}(4)$

$\mathrm{S}_{2} \mathrm{O}_{8}{ }^{2-}+\mathrm{S}_{\mathrm{n}}{ }^{2-} \rightarrow 2 \mathrm{SO}_{4}{ }^{2-}+\mathrm{S}^{0}(5)$

$\mathrm{S}_{\mathrm{n}}{ }^{2-}+2 \mathrm{Fe}^{3+}\left(\mathrm{Cu}^{2+}\right) \rightarrow \mathrm{S}^{0}+2 \mathrm{Fe}^{2+}\left(\mathrm{Cu}^{+}\right)(6)$

$\mathrm{H}_{2} \mathrm{O}_{2}+\mathrm{HO} \cdot \rightarrow \mathrm{HO}_{2}+\mathrm{H}_{2} \mathrm{O}(7)$

$\mathrm{H}_{2} \mathrm{O}_{2}+\mathrm{HO}_{2} \rightarrow \mathrm{HO} \cdot \mathrm{H}_{2} \mathrm{O}+\mathrm{O}_{2}(8)$

\subsubsection{Effect of initial NBo dose}

As shown in Fig. $1 \mathrm{c}$ and d, the degradation rates of MNC was $14.67 \%$ and $11.07 \%$, respectively, after the addition of $500 \mu \mathrm{M}$ PS or $\mathrm{H}_{2} \mathrm{O}_{2}$ alone, which implied that the MNC with stable structure could not be effectively degraded by PS or $\mathrm{H}_{2} \mathrm{O}_{2}$ separately. Evidently, the amount of activator directly affects the removal efficiency of target pollutants. Previous studies showed that with the increase of the transition metal ions (e.g., $\mathrm{Fe}^{2+}$, and $\mathrm{Cu}^{+}$) concentration, more $\mathrm{SO}_{4}{ }^{-{ }^{-}}$and $\mathrm{HO} \cdot$ were produced in the NBo/PS and $\mathrm{NBo} / \mathrm{H}_{2} \mathrm{O}_{2}$ processes, which resulted in the degradation rate of target pollutants increased (Zhang et al. 2020). With the concentration of initial oxidants ( $P S$ and $\mathrm{H}_{2} \mathrm{O}_{2}$ ) fixed at $500 \mu \mathrm{M}$, with the dosage of NBo increased from $0.00 \mathrm{~g} / \mathrm{L}$ to $0.15 \mathrm{~g} / \mathrm{L}$ the degradation rate of $\mathrm{MNC}$ was increased.

Interestingly, when the dosage of NBo was $0.05 \mathrm{~g} / \mathrm{L}$, the degradation rates of MNC by the two oxidation processes was quite different. The reason was that the concentration of oxidants ( $P S$ and $\mathrm{H}_{2} \mathrm{O}_{2}$ ) far exceeded that of the activator at this time, and the second-order reaction rate constants $(k)$ of the selfquenching reaction caused by oxidants are quite different, with $k_{\mathrm{PS}}=6.5^{*} 10^{5} \mathrm{~L} /(\mathrm{mol} \cdot \mathrm{s})$ and $k_{\mathrm{H} 202}=3.3^{*} 10^{7} \mathrm{~L} /(\mathrm{mols})$ (Feng et al. 2018). When the dosage of NBo was $0.1 \mathrm{~g} / \mathrm{L}$, there was almost no slow reaction stage in the $\mathrm{NBo} / \mathrm{H}_{2} \mathrm{O}_{2}$ process because $\mathrm{Cu}^{2+}$ could rapidly react with the $\mathrm{HO}_{2}{ }_{2}$ generated in the reaction $\left(k_{\mathrm{HO}_{2}}=1.6 * 10^{8} \mathrm{~L} /(\mathrm{mol} \cdot \mathrm{s})\right)$, and the reduced $\mathrm{Fe}^{3+}$ continues to participate in the chain reaction (Eqs. (1), (7), (9)). Nevertheless, when the dosage of NBo increased to $0.2 \mathrm{~g} / \mathrm{L}$, the degradation rate of $\mathrm{MNC}$ in both the NBo/PS and $\mathrm{NBo} / \mathrm{H}_{2} \mathrm{O}_{2}$ processes decreased. Because excessive NBo increased the turbidity of the solution, promoted NBo agglomeration and reduced the activated sites on NBo 
surface. In addition, excessive metal ions (e.g., $\mathrm{Fe}^{2+}$ and $\mathrm{Cu}^{+}$) consumed free radicals (i.e., $\mathrm{SO}_{4}{ }^{-{ }^{-}}$and $\mathrm{HO}$ ), which inhibited the degradation of MNC (Eqs. (10), (11)) (Wang et al. 2014).

$\mathrm{Cu}^{2+}+\mathrm{HO}_{2} \rightarrow \mathrm{Cu}^{+}+\mathrm{H}^{+}+\mathrm{O}_{2}(9)$

$\mathrm{Cu}^{+}+\mathrm{Fe}^{3+} \rightarrow \mathrm{Fe}^{2+}+\mathrm{Cu}^{2+}(10)$

$\mathrm{SO}_{4}{ }^{-}+\mathrm{Fe}^{2+}\left(\mathrm{Cu}^{+}\right) \rightarrow \mathrm{SO}_{4}{ }^{2-}+\mathrm{Fe}^{3+}\left(\mathrm{Cu}^{2+}\right)(11)$

$\mathrm{HO} \cdot+\mathrm{Fe}^{2+}\left(\mathrm{Cu}^{+}\right) \rightarrow \mathrm{HO}^{-}+\mathrm{Fe}^{3+}\left(\mathrm{Cu}^{2+}\right)(12)$

\subsubsection{Effect of inorganic anions}

Many studies showed that degradation rates of pollutants in AOPs was affected by inorganic anions in water (Avetta et al. 2015; Sharma et al. 2018; Yang et al. 2019). In this study, typical inorganic anions (i.e., $\mathrm{Cl}^{-}, \mathrm{NO}_{3}{ }^{-}$, and $\mathrm{HCO}_{3}{ }^{-}$) were selected to investigated the effect of different anion concentrations (i.e., $10 \mathrm{mM}, 20 \mathrm{mM}$, and $50 \mathrm{mM}$ ) on the degradation of $\mathrm{MNC}$ in the $\mathrm{NBo} / \mathrm{PS}$ and $\mathrm{NBo} / \mathrm{H}_{2} \mathrm{O}_{2}$ processes. As shown in Fig. 2a and b, three inorganic anions with a concentration of 10-50 mM inhibited the two processes to varying degrees. In the presence of $10-50 \mathrm{mM} \mathrm{Cl}^{-}$, the degradation rate of $\mathrm{MNC}$ in the $\mathrm{NBo} / \mathrm{PS}$ process decreased to $79.78 \%, 79.59 \%$, and $67.89 \%$, while that in the $\mathrm{NBo} / \mathrm{H}_{2} \mathrm{O}_{2}$ process decreased to $81.87 \%, 58.01 \%$, and $36.63 \%$. Similarly, degradation of MNC was significantly inhibited in the presence of higher concentration of $\mathrm{NO}_{3}{ }^{-}$. Equally, $\mathrm{HCO}_{3}{ }^{-}$was also considered a quencher of free radicals, which had a certain negative impact on AOPs (Wang and Wang 2018). The degradation rates of MNC reduced to $38.38 \%$ and $36.49 \%$ with $10 \mathrm{mM} \mathrm{HCO}_{3}{ }^{-}$in the $\mathrm{NBo} / \mathrm{PS}$ and $\mathrm{NBo} / \mathrm{H}_{2} \mathrm{O}_{2}$ processes. However, when the $\mathrm{HCO}_{3}{ }^{-}$concentration increased to $50 \mathrm{mM}$, the degradation rates of MNC increased to $79.91 \%$ and $70.30 \%$, respectively.

$\mathrm{Cl}^{-}$could react with $\mathrm{SO}_{4}{ }^{--}\left(k_{\mathrm{Cl}-}=1.3-6.6^{*} 10^{8} /\left(\mathrm{M}^{-1} \mathrm{~S}^{-1}\right)\right)$ and $\mathrm{HO} \cdot\left(k_{\mathrm{Cl}}=3.0-4.3^{*} 10^{9} /\left(\mathrm{M}^{-1} \mathrm{~S}^{-1}\right)\right)$ to generate relatively weak chlorine radicals (e.g., $\left.\mathrm{Cl}^{\prime}, \mathrm{Cl}_{2}{ }^{-}^{-} \mathrm{ClOH}^{-}\right)$and free chlorine $\left(\mathrm{Cl}_{2}\right)$. Similarly, $\mathrm{NO}_{3}{ }^{-}$could also react with $\mathrm{SO}_{4}{ }^{--}$to generate $\mathrm{NO}_{2}{ }^{--}, \mathrm{NO}_{3}{ }^{-{ }^{-}}, \mathrm{N}_{2}$, etc. Since the relative activity of the generated free radicals was weaker than that of $\mathrm{SO}_{4}{ }^{-}$and $\mathrm{HO}$, the degradation rates of $\mathrm{MNC}$ reduced in the presence of $\mathrm{Cl}^{-}$and $\mathrm{NO}_{3}{ }^{-}$in the $\mathrm{NBo} / \mathrm{PS}$ and $\mathrm{NBo} / \mathrm{H}_{2} \mathrm{O}_{2}$ processes. It was not difficult to see that $\mathrm{Cl}^{-}$and $\mathrm{NO}_{3}{ }^{-}$had major inhibitory effects on the $\mathrm{NBo} / \mathrm{H}_{2} \mathrm{O}_{2}$ process. This was similar to the results of $\mathrm{Neta}$ et al. (1977), wherein $\mathrm{SO}_{4}{ }^{-}$-based AOPs were more stable than $\mathrm{HO}$--based AOPs.

Although $\mathrm{HCO}_{3}{ }^{-}$could also react with $\mathrm{SO}^{-} \cdot^{-}\left(k_{\mathrm{HCO} 3}=2.1-9.6 * 10^{6} /\left(\mathrm{M}^{-1} \mathrm{~S}^{-1}\right)\right)$ and $\mathrm{HO}$.

$\left(k_{\mathrm{HCO}-}=\mathrm{n}^{\star} 10^{7} /\left(\mathrm{M}^{-1} \mathrm{~S}^{-1}\right)\right)$ to form relatively weak free radicals $\left(\right.$ e.g., $\mathrm{HCO}_{3}$, and $\left.\mathrm{CO}_{3}{ }^{-{ }^{-}}\right)$, the mechanism of $\mathrm{HCO}_{3}{ }^{-}$inhibition of the reaction was different from that of $\mathrm{Cl}^{-}$and $\mathrm{NO}_{3}{ }^{-}$. As mentioned earlier, the degradation rates of $\mathrm{MNC}$ increased with increase of $\mathrm{HCO}_{3}{ }^{-}$concentrations. On the one hand, carbonate radicals could react well with electron-rich pollutant such as $\mathrm{MNC}$. On the other hand, the $\mathrm{pH}$ of the 
solution increased by the addition of buffer salt $\mathrm{HCO}_{3}{ }^{-}$, which resulted in the leaching of copper ions reduced. At that time, $\mathrm{HCO}_{3}{ }^{-}$had good complexing ability with $\mathrm{Fe}^{2+}$ and $\mathrm{Cu}^{2+}$, which was the main reason for the increase of MNC degradation rates. Previous studies also found that the degradation of phenol and the TOC were improved in the presence of $\mathrm{HCO}_{3}{ }^{-}$in the $\mathrm{CuO}-\mathrm{Fe}_{3} \mathrm{O}_{4}$ process (Lei et al. 2015). In addition, the high concentration of $\mathrm{HCO}_{3}{ }^{-}$contributed to produce $\mathrm{SO}_{4}{ }^{-{ }^{-}}$and $\mathrm{HO}$. from PS and $\mathrm{H}_{2} \mathrm{O}_{2}$, to enhance the MNC degradation.

\subsubsection{Effect of pH}

$\mathrm{pH}$ plays an important role in heterogeneous AOPs based on free radicals ( $\mathrm{Li}$ et al. 2020). The typical pH of most natural water bodies is between 3 and 9 , so it is necessary to investigate the influence of the initial $\mathrm{pH}$ of the solution on AOPs, and the degradation kinetics are presented in Fig. S1a and b (Feng et al. 2017). Figure $2 \mathrm{c}$ summarized the $\mathrm{MNC}$ degradation rates with different initial $\mathrm{pH}$ of the solution in the $\mathrm{NBo} / \mathrm{PS}$ and $\mathrm{NBo} / \mathrm{H}_{2} \mathrm{O}_{2}$ processes after $180 \mathrm{~min}$. Obviously, these two processes had a better MNC degradation rates under acidic $\mathrm{pH}$ because acidic condition was conducive to the dissolution of metal ionsto activate PS or $\mathrm{H}_{2} \mathrm{O}_{2}$ to produce more free radicals. When the $\mathrm{pH}$ was 6.5 , the degradation rates in the $\mathrm{NBo} / \mathrm{PS}$ and $\mathrm{NBo} / \mathrm{H}_{2} \mathrm{O}_{2}$ processes were sharply decreased to $67.37 \%$ and $54.52 \%$, respectively. With increase of $\mathrm{pH}$, the degradation rates increased until $\mathrm{pH}=7.5$. After that, the degradation rates decreased as the $\mathrm{pH}$ increased to 9.5 , because $\mathrm{Fe}^{2+}$ precipitated easily under alkaline $\mathrm{pH}$ conditions. Interestingly, when the $\mathrm{pH}$ increased from 6.5 to 9.5, the degradation rates of MNC in the NBo/PS process always higher than that of in the $\mathrm{NBo} / \mathrm{H}_{2} \mathrm{O}_{2}$ process because $\mathrm{SO}_{4}{ }^{-{ }^{-}}$could react with $\mathrm{OH}^{-}$to form $\mathrm{HO}$ - with strong catalytic activity under alkaline conditions. In the $\mathrm{NBo} / \mathrm{H}_{2} \mathrm{O}_{2}$ process, $\mathrm{H}_{2} \mathrm{O}_{2}$ was decomposed under alkaline conditions to reduce the amount of $\mathrm{HO}$ - and oxidation ability of hydroxyl radicals according to Nernst equation (Eqs. (13)).

$\mathrm{E}^{0}=\mathrm{E}^{0} \mathrm{HO}_{\mathrm{H}} / \mathrm{H} 2 \mathrm{O}-0.059 \mathrm{pH}$ (13)

Compared with the higher $\mathrm{pH}$, the loss of activated ability at $\mathrm{pH} 6.5$ may be due to the formation of a barrier layer on the surface of the material caused by the precipitation of iron ions, which limited the activated ability of the material (Liu et al. 2019). With continuously increase of $\mathrm{pH}$, although the problem of ion precipitation still existed, the high $\mathrm{pH}$ was beneficial to the formation of hydroxyl groups on the activator surface, which served as the center of electron transfer activityto improve the activated performance of the activator. It was worth noting that after $180 \mathrm{~min}$ of reaction, the $\mathrm{pH}(2.5-9.5)$ of all solutions decreased due to the hydrolysis of ferrous ions and the formation of acidiic intermediate products. Moreover, acidic conditions resulted in a high degradation rate of MNC in the two processes, indicated that AOPs based on the $\mathrm{NBo} / \mathrm{PS}$ and $\mathrm{NBo} / \mathrm{H}_{2} \mathrm{O}_{2}$ processes had high application value in degradation of pollutants such as $\mathrm{MNC}$ in a wide $\mathrm{pH}$ range.

\subsection{Identification of dominant reactive radicals}


In this study, EtOH and TBA were selected as quenchers to participate in the reaction. As suggested, EtOH contains an a-hydrogen that reacts with $\mathrm{SO}_{4}{ }^{--}$at a rate of $1.6-7.7 * 10^{7} \mathrm{M}^{-1} \mathrm{~S}^{-1}$ and $\mathrm{HO}$ at a rate of 1.2$2.8^{\star} 10^{9} \mathrm{M}^{-1} \mathrm{~S}^{-1}$. The reaction rate of TBA without a-hydrogen with $\mathrm{HO} \cdot\left(3.8-7.6^{*} 10^{8} \mathrm{M}^{-1} \mathrm{~S}^{-1}\right)$ is much higher than that of $\mathrm{SO}_{4}{ }^{-}{ }^{-}\left(4-9.1 * 10^{5} \mathrm{M}^{-1} \mathrm{~S}^{-1}\right)$ (Lei et al. 2015; Wu et al. 2019). As shown in Fig. 3 , in the NBo/PS system, the degradation rate of MNC was $86.48 \%$ after $180 \mathrm{~min}$ in the absence of a quencher, but after the addition of $50 \mathrm{mM} \mathrm{EtOH}$ and TBA, the degradation rate was reduced to $41.82 \%$ and $77.20 \%$, respectively. The results showed that $\mathrm{SO}_{4}{ }^{-}{ }^{-}$was the main activated species in the NBo/PS process. In the $\mathrm{NBo} / \mathrm{H}_{2} \mathrm{O}_{2}$ system, the degradation rate of $\mathrm{MNC}$ was $87.47 \%$ after 180 min without a quencher and decreased to $50.62 \%$ and $56.80 \%$ after the addition of $50 \mathrm{mM}$ EtOH and TBA, respectively. EtOH and TBA had a greater inhibitory effect on the degradation of $\mathrm{MNC}$ in the $\mathrm{H}_{2} \mathrm{O}_{2}$ process than in the other process, indicated that $\mathrm{HO}$ - was the main factor in the $\mathrm{NBo} / \mathrm{H}_{2} \mathrm{O}_{2}$ system. It was not difficult to see that higher concentrations of EtOH and TBA could not completely inhibit the degradation of MNC in the two systems. Studies pointed out that EtOH and TBA with high hydrophilicitycould not accumulate on the surface of the activator or effectively capture free radicals bound on the surface of the activatorto completely terminate the reaction in a heterogeneous process. Concurrently, the formation of superoxide radicals $\left(\mathrm{O}_{2}{ }^{--}\right)$in the heterogeneous process was promoted by the dissolved oxygen in the solution during the degradation process, and the free radicals converted by chain reactions (such as $\mathrm{S}_{2} \mathrm{O}_{8}{ }^{\cdot-}$, and $\mathrm{HO}_{2}$ ) contributed to the degradation of MNC in the presence of quenchers. In addition, Fig. S3 provides a quantitative analysis of $\mathrm{HO} \cdot$ in the $\mathrm{NBo} / \mathrm{PS}$ and $\mathrm{NBo} / \mathrm{H}_{2} \mathrm{O}_{2}$ processes.

The generated activated species were further detected by EPR. As shown in Fig. $3 \mathrm{c}$ and d, in the NBo/PS process, the spectra of DMPO-HO and DMPO- $\mathrm{SO}_{4}{ }^{-}$adductwere clearly observed. In the $\mathrm{NBo} / \mathrm{H}_{2} \mathrm{O}_{2}$ process, EPR signals of $\mathrm{SO}_{4}{ }^{-}$and $\mathrm{HO}$. were also observed because the formation of small amount of $\mathrm{SO}_{4}{ }^{--}$through a series of chain reactions even though leaching of $\mathrm{S}^{2-}$ caused by NBo. The above results indicated that the free radicals in the solution were the main reason for MNC degradation.

\subsection{Characterization of NBo}

To discuss the composition and electronic properties of NBo surface elements, the XPS spectra of NBo were studied. As shown in Fig. 4a, the XPS spectra showed that NBo was mainly composed of $\mathrm{Cu}, \mathrm{Fe}, \mathrm{O}$, $\mathrm{S}$, Si and Al, which was consistent with the XRD and XRF results (Fig. S4 and Table S5). C and $O$ might be originated from the adsorption of air by NBo powder samples (e.g., Si and Al) during the XPS test (Nie et al. 2019). According to the high-resolution spectra of $\mathrm{Cu} 2 \mathrm{p}$, the fresh and used NBo had strong Cu 2p3 and $\mathrm{Cu} 2 \mathrm{p} 1$ peaks near $932.2 \mathrm{eV}$ and $951.1 \mathrm{eV}$, respectively, and obvious satellite peaks were observed in $\mathrm{Cu} 2 \mathrm{p}$. Because the binding energies of $\mathrm{CuS}$ and $\mathrm{Cu}_{2} \mathrm{~S}$ were too close to $932.2 \mathrm{eV}$ and $932.5 \mathrm{eV}$, respectively, it was impossible to accurately distinguish the valence state of Cu near $932.2 \mathrm{eV}$. However, according to the analysis of $\mathrm{Cu} 2 \mathrm{p} 3$, the $\mathrm{Cu}$ on the surface of fresh and used NBo was mostly in the + 2oxidation state. It can be seen from the changes in the Cu-S and $\mathrm{Cu}$ (II) contents that there was not much difference in the valence content of Cu before and after the use of NBo, which indicated that the activator 
could continuously release stable $\mathrm{Cu}$ in the valence state to be used repeatedly. Figure 4c shows the highresolution Fe 2p spectra of the fresh and used NBo. Fe 2p3 and Fe 2p1 characteristic peaks appeared at $708 \mathrm{eV}, 709.8 \mathrm{eV}, 711.58 \mathrm{eV}, 720.8 \mathrm{eV}, 722.6 \mathrm{eV}$, and $724.98 \mathrm{eV}$, respectively. Fe 2p satellite peaks appeared at $713.52 \mathrm{eV}, 717.38 \mathrm{eV}, 727.83 \mathrm{eV}$ and $731.04 \mathrm{eV}$, all of which indicated that the surface of NBo had the characteristics of Fe (II) and Fe (III). After being used, the ratio of Fe (II) on the NBo surface decreased from $52.15-45.51 \%$, which indicated that active performance of NBo repeated use would slightly decrease the. In addition,the peak positions of $\mathrm{Fe}_{0}, \mathrm{Fe}$ (II) and $\mathrm{Fe}$ (III) in the used sample present an obviously negative shifting compared to the fresh sample, this results indicated electron transfer phenomenon during activation. Figure $4 \mathrm{~d}$ shows the high-resolution $S 2 p$ spectrogram before and after use. At $162.30 \mathrm{eV}, 163.81 \mathrm{eV}, 164.76 \mathrm{eV}$ and $168.74 \mathrm{eV}$, the characteristic peaks corresponded to $\mathrm{S}^{2-}, \mathrm{S}_{\mathrm{n}}{ }^{2-}$, $\mathrm{S}_{0}$ and $\mathrm{SO}_{4}{ }^{2-}$, respectively. Clearly, the contents of $\mathrm{S}_{\mathrm{n}}{ }^{2-}$ and $\mathrm{SO}_{4}{ }^{2-}$ in NBo increased from $19.10 \%$ and $2.66-25.53 \%$ and $11.03 \%$, respectively, and the content of $S_{0}$ hardly changed, while the content of $S^{2-}$ decreased from $68.10-53.91 \%$. Results showed that during the reaction, $S^{2-}$ was converted into $S_{n}{ }^{2-}, S_{0}$ and $\mathrm{SO}_{4}{ }^{2-}$ in sequence; the content of $\mathrm{S}_{0}$ decreased slightly, possibly because it was partially consumed as a reducing agent in the reaction with $\mathrm{Fe}$ (III) and $\mathrm{Cu}$ (II).

\subsection{Degradation products and pathways}

The degradation products of MNC were determined by I-Class-VION-IMS-Qtof. Fig. S5a and b showed the total ion chromatogram (TIC) of the oxidative degradation of $\mathrm{MNC}$ in the NBo/PS and $\mathrm{NBo} / \mathrm{H}_{2} \mathrm{O}_{2}$ processes, respectively. The appearance of new peaks and different intensities in the ion chromatogram indicated the formation of new substances (Taha et al. 2016; Dulova et al. 2017; Zhang et al. 2020). The possible degradation pathway of MNC was showed in Fig. 5. Fourteen potential degradation intermediates were observed in the NBo/PS process at elution times of $2.14 \mathrm{~min}, 3.11 \mathrm{~min}, 3.64 \mathrm{~min}$ and $3.84 \mathrm{~min}$, while ten potential degradation intermediates of the $\mathrm{NBo} / \mathrm{H}_{2} \mathrm{O}_{2}$ process were observed at elution times of $0.36 \mathrm{~min}, 2.14 \mathrm{~min}, 3.13 \mathrm{~min}, 3.45 \mathrm{~min}, 3.64 \mathrm{~min}$ and $3.83 \mathrm{~min}$. The mineralization rates were $33.96 \%$ and $29.94 \%$ in NBo/PS and $\mathrm{NBo} / \mathrm{H}_{2} \mathrm{O}_{2}$ process, respectively. In the NBo/PS process, MNC was firstly attacked by active specoes in aqueous solution and converted into $\mathrm{P} 1(\mathrm{~m} / \mathrm{z}=370)$ by ring opening, and then P2 (m/z = 337), P3 (m/z = 316) and P5 (m/z = 237) were further generated by deamidation of P1. Xu et al. (2017) showed that the cleavage of $\mathrm{C}-0$ bonds and the hydroxylation of target substances were the main mechanisms for the degradation of pollutants by free radical systems. In the same way, the organic compounds P4 ( $\mathrm{m} / \mathrm{z}=281), \mathrm{P} 6(\mathrm{~m} / \mathrm{z}=269), \mathrm{P} 7(\mathrm{~m} / \mathrm{z}=260), \mathrm{P} 8(\mathrm{~m} / \mathrm{z}=255)$, $\mathrm{P} 10(\mathrm{~m} / \mathrm{z}=204)$ and p14 (m/z = 135), with smaller relative molecular weights, were further obtained by the ring-opening reaction of $\mathrm{P} 2$ and $\mathrm{P} 3$. It has been reported that $\mathrm{HO}$. can react with pollutants by direct addition or electron transfer and then form different reaction products (Zhang et al. 2016). Figure $5 \mathrm{~b}$ shows the possible degradation pathway of $\mathrm{MNC}$ by the $\mathrm{NBo} / \mathrm{H}_{2} \mathrm{O}_{2}$ process. First, the hydroxyl group replaced the $\mathrm{H}$ in the $\mathrm{C}-\mathrm{H}$ bond and adducted with pollutants to form TP1 $(\mathrm{m} / \mathrm{z}=473)$. TP1 was decomposed to $\mathrm{P} 2(\mathrm{~m} / \mathrm{z}=445)$ via deamidation reaction. Then, $\mathrm{P} 2$ was further degraded into the smaller mass organic substances P3 $(\mathrm{m} / \mathrm{z}=337)$ and P4 $(\mathrm{m} / \mathrm{z}=309)$ by ring-opening reaction under the action of 
$\mathrm{HO}$. The cyclic pollutants were oxidized to hydroxylated derivatives and further decomposed into degradable pollutants (TP5-TP10) under the action of HO. In addition, substances with relatively low mass responses were generated in those two systems, which might be secondary intermediates generated in the degradation process.

The possible mechanisms and degradation pathways based on the oxidative degradation of MNC in $\mathrm{NBo} / \mathrm{PS}$ and $\mathrm{NBo} / \mathrm{H}_{2} \mathrm{O}_{2}$ processes were as follows: a large number of free radicals (mainly $\mathrm{SO}_{4}{ }^{-{ }^{-}}$and $\mathrm{HO} \cdot$ ) were generated under the action of activators and oxidants in the system, which were dispersed to the NBo surface and MNC solution. On the one hand, the C-C bond of MNC was destroyed by electron transfer, and a deamidation reaction occurs to generate pollutants with ring structures (P1, P12), and the $\mathrm{C}-\mathrm{C}$ bond and $\mathrm{C}=\mathrm{O}$ bond of the pollutants were further destroyed to generate small molecules. On the other hand, one active site of the pollutants was replaced by free radicals to form adducts (TP1). The C-C bonds and $\mathrm{C}=\mathrm{O}$ bonds of TP1 were further oxidized to form the hydroxylated derivative. Finally, these intermediates were further oxidized to carbon dioxide and $\mathrm{H}_{2} \mathrm{O}$ to achieve inorganic treatment of pollutants.

\subsection{Degradation of MNC in natural water}

To evaluate the feasibility of NBo activating PS and $\mathrm{H}_{2} \mathrm{O}_{2}, \mathrm{MNC}$ removal by the two processes in natural water matrix (Table S4) was studied. The $\mathrm{pH}$ of the collected water samples (i.e., tap water and river water) was between 7 and 8 . The experiment was carried out under optimal conditions. As shown in Fig. 6, the degradation rates of MNC in natural water was lower than that in ultrapure water. Clearly, the degradation rate achieved with the NBo/PS and $\mathrm{NBo} / \mathrm{H}_{2} \mathrm{O}_{2}$ processes in the untreated river water matrix was lower than that in tap water. Because the existence of a large number of anions in river water with alkaline condition, the formation of metal ions was aggravated. As mentioned above, $\mathrm{pH}$ had an important influence on the two systems in this study. The degradation of MNC was significantly improved in both system by adjust the $\mathrm{pH}$ of river water and tap water to 4.5 with $0.1 \mathrm{M} \mathrm{H}_{2} \mathrm{SO}_{4}$ and $\mathrm{NaOH}$. The results indicated that degradation of pollutants with different water matrices in the NBo/PS and $\mathrm{NBo} / \mathrm{H}_{2} \mathrm{O}_{2}$ systems were inhibited because of high $\mathrm{pH}$. Consistent with the results of Sect. 3.1.4, $\mathrm{SO}_{4}{ }^{--}-$ based AOPs were more stable than HO--based AOPs in different water materials. In short, MNC could be effectively degraded in natural waters by adjusting the $\mathrm{pH}$ appropriately. Results obtained in this study showed that the degradation of MNC based on the NBo/PS and $\mathrm{NBo} / \mathrm{H}_{2} \mathrm{O}_{2}$ systems had high industrial application potential.

\subsection{Reusability of NBo activator}

To evaluate the stability of the activator, the reaction solution was suction filtered after 180 min of reaction, and the retained NBo was washed repeatedly with $2 \mathrm{~L}$ of ultrapure water and finally dried under vacuum at $60^{\circ} \mathrm{C}$. The stability of $\mathrm{NBo}$ in the two processes (NBo/PS and $\mathrm{NBo} / \mathrm{H}_{2} \mathrm{O}_{2}$ processes) was evaluated on the basis of its reusability. Figure 7a showed that NBo still had high activated performance for PS after repeatedly use three times in the NBo/PS process. Compared with the unused NBo, the 
degradation rate of MNC decreased by $4.59 \%$ after second run for $180 \mathrm{~min}$, which indicated that NBo had excellent reusability in the NBo/PS process. Figure $7 \mathrm{~b}$ showed that in the $\mathrm{NBo} / \mathrm{H}_{2} \mathrm{O}_{2}$ process, after second and third reactions, the degradation rate of $\mathrm{MNC}$ decreased by $8.28 \%$ and $9.00 \%$, respectively. The slight decrease of the MNC removal rate might be due to the precipitation of metal ions during reaction, resulted in slight changes of the surface element distribution. In brief, NBo had considerable stability in activating PS and $\mathrm{H}_{2} \mathrm{O}_{2}$ to degrade MNC.

\subsection{Toxicity evaluation}

The ultimate goal of degrading pollutants through AOPs is to eliminate the harm of pollutants to aquatic organisms and humans. However, in the process of pollutant degradation, the transformation of macromolecular substances into small molecular substances will cause change in the properties of the substances (Long et al. 2014; Yao et al. 2019). Therefore, it is important to evaluate the change of toxicity during the degradation of MNC solutions.

The luminescence inhibition rate of the MNC aqueous solution was showed in Figs. 8 and S2. In general, the biological toxicity of MNC tended to decrease after degradation. The results of toxicity assessment were closely related to the properties of MNC degradation products. In the $\mathrm{NBo} / \mathrm{H}_{2} \mathrm{O}_{2}$ system, the inhibition rate decreased to $49.92 \%$ after 30 min of reaction because the products (TP3, TP4) with lower biological toxicity produced by the ring-opening reaction at this time. It was obvious that the toxicity after $90 \mathrm{~min}$ and $180 \mathrm{~min}$ was greater than that after $30 \mathrm{~min}$, which due to the formation of more hydroxylated derivatives (TP5-TP9) during the degradation of MNC, and the hydroxylated derivatives were not further degraded within $180 \mathrm{~min}$. In the NBo/PS system, toxic degradation products such as hydroxylated derivatives (P2, P3, P12) and carbonylation derivatives (P9, P11) were also produced. However, these organic substances could be decomposed into degradable organic substances (P11, P13, P14). Therefore, the toxicity of degraded MNC was lower than that of the parent compound. The results of the toxicity test showed that the NBo/PS and $\mathrm{NBo} / \mathrm{H}_{2} \mathrm{O}_{2}$ systems were effective ways to degrade MNC.

\section{Conclusions}

In this study, the degradation of MNC under different experimental parameters in NBo/PS and $\mathrm{NBo} / \mathrm{H}_{2} \mathrm{O}_{2}$ systems was investigated. The main conclusions are as follows.

NBo can effectively activate PS and $\mathrm{H}_{2} \mathrm{O}_{2}$ to degrade MNC. After reaction for $180 \mathrm{~min}$, the efficiencies of MNC degradation in the two processes were $86.40 \%$ and $87.50 \%$, and the mineralization rates were $33.96 \%$ and $29.94 \%$, respectively. The metal ions and reductive $S$ released from NBo play an important role in enhancing the degradation rates. The NBo and oxidant dosages have an important influence on the degradation of MNC, and a high $\mathrm{pH}$ can inhibit the MNC degradation. The identification of intermediate products shows that degradation of MNC in the two processes was achieved by free radical addition and electron transfer, respectively, and the degradation pathways mainly include ring-opening reactions and deamidation reactions. The natural water components $\mathrm{Cl}^{-}$and $\mathrm{NO}_{3}{ }^{-}$have inhibitory effects 
on NBo/PS and $\mathrm{NBo} / \mathrm{H}_{2} \mathrm{O}_{2}$ processes, and the inhibitory effect is proportional to the concentration of $\mathrm{Cl}^{-}$ and $\mathrm{NO}_{3}{ }^{-}$, while the inhibitory effect of $\mathrm{HCO}_{3}{ }^{-}$on the reaction is inversely proportional to its concentration. $\mathrm{NBo} / \mathrm{PS}$ and $\mathrm{NBo} / \mathrm{H}_{2} \mathrm{O}_{2}$ processes have strong industrial application potential of degradation of pollutants because the degradation rate of MNC was similar to that in ultrapure water through adjust the $\mathrm{pH}$ of different water source.To the best of our knowledge, this is the first study on the degradation of organic pollutants by activating PS and $\mathrm{H}_{2} \mathrm{O}_{2}$ with $\mathrm{Fe}-\mathrm{Cu}$ bimetallic sulfide; moreover, there has been no previous report on the degradation mechanism and reaction pathway of MNC pollutants. This work will provide a new perspective for the mechanism of Fe-Cu bimetallic sulfide activation of PS and $\mathrm{H}_{2} \mathrm{O}_{2}$ degradation of pollutants.

\section{Abbreviations}

Natural bornite (NBo); minocycline (MNC); persulfate (PS); hydrogen peroxide $\left(\mathrm{H}_{2} \mathrm{O}_{2}\right)$; advanced oxidation processes (AOPs)

\section{Declarations}

We declare that we do not have any commercial or associative interest that represents a conflict of interest in connection with the work submitted.

\section{Ethics approval and consent to participate}

Not applicable.

\section{Consent for publication}

Not applicable.

\section{Availability of data and materials}

The data used to support the findings of this study are available from the corresponding author upon request.

\section{Competing interests}

The authors declare that they have known competing financial interests or personal relationships that could have appeared to influence the work reported in this paper.

\section{Funding}

This work was supported by the Shaanxi Key Science and Technology Innovation Team Project (Grant No. 2017KCT-19-01), the Shaanxi Innovation and Guidance Special Project (Grant No. 2018HJCG-18). 


\section{Authors' contributions}

Taikang Yuan $₫$ Design experiment, conduct experiment, write papers

Xudong Wang $₫$ Provide funds $₫$ guide experiment $₫$ modify this paper

Xiaochen Zhao: Assist experiment, Verify experiment

Tingting Liu: modify this paper

Hongmin Zhang: Assist experiment

Yongtao Lv: Guide experiment

Lei Wang: Guide experiment

\section{Acknowledgements}

This work was supported by the Shaanxi Key Science and Technology Innovation Team Project (Grant No. 2017KCT-19-01), the Shaanxi Innovation and Guidance Special Project (Grant No. 2018HJCG-18).

\section{References}

Avetta P, Pensato A, Minella M, Malandrino M, Maurino V, Minero C, Hanna K, Vione D (2015) Activation of persulfate by irradiated magnetite: implications for the degradation of phenol under heterogeneous photo-Fenton-like conditions. Environ Sci Technol 49:1043-1050. https://doi.org/10.1021/es503741d

Basiri S, Mehdinia A, Jabbari A (2018) A sensitive triple colorimetric sensor based on plasmonic response quenching of green synthesized silver nanoparticles for determination of $\mathrm{Fe}^{2+}$, hydrogen peroxide, and glucose. Colloids Surf A Physicochem Eng Asp 545:138-146.

https://doi.org/10.1016/j.colsurfa.2018.02.053

Bi W, Wu Y, Dong W (2020) The degradation of oxytetracycline with low concentration of persulfate sodium motivated by copper sulphate under simulated solar light. Chem Eng J 393:122782. https://doi.org/10.1016/j.cej.2019.122782

Cai C, Zhang H, Zhong X, Hou L (2014) Electrochemical enhanced heterogeneous activation of peroxydisulfate by Fe-Co/SBA-15 catalyst for the degradation of orange II in water. Water Res 66:473-485. https://doi.org/10.1016/j.watres.2014.08.039

Cashman MA, Kirschenbaum L, Holowachuk J, Boving TB (2019) Identification of hydroxyl and sulfate free radicals involved in the reaction of 1,4-dioxane with peroxone activated persulfate oxidant. $J$ Hazard Mater 380:120875. https://doi.org/10.1016/j.jhazmat.2019.120875 
Dulova N, Kattel E, Trapido M (2017) Degradation of naproxen by ferrous ion-activated hydrogen peroxide, persulfate and combined hydrogen peroxide/persulfate processes: the effect of citric acid addition. Chem Eng J 318:254-263. https://doi.org/10.1016/j.cej.2016.07.006

Fan JW, Wu HX, Liu RY, Meng LY, Sun YJ (2021) Review on the treatment of organic wastewater by discharge plasma combined with oxidants and catalysts. Environ Sci Pollut R 28:2522-2548. https://doi.org/10.1007/s11356-020-11222-z

Feng Y, Liu X, Huynh KA, Mccaffery JM, Mao L, Gao S, Chen KL (2017) Heteroaggregation of graphene oxide with nanometer- and micrometer-sized hematite colloids: influence on nanohybrid aggregation and microparticle sedimentation. Environ Sci Technol 51:6821-6828.

https://doi.org/10.1021/acs.est.7b00132

Feng Y, Wu D, Li H, Bai J, Hu Y, Liao C, Li XY, Shih K (2018) Activation of persulfates using siderite as a source of ferrous ions: sulfate radical production, stoichiometric efficiency, and implications. ACS Sustainable Chem Eng 6:3624-3631. https://doi.org/10.1021/acssuschemeng.7b03948

Giannakis S, Lin KYA, Ghanbari F (2021) A review of the recent advances on the treatment of industrial wastewaters by sulfate radical-based advanced oxidation processes (SR-AOPs). Chem Eng J 406:127083. https://doi.org/10.1016/j.cej.2020.127083

Huang H, Guo G, Tang S, Li B, Zhao N (2020) Persulfate oxidation for alternative sludge treatment and nutrient recovery: an assessment of technical and economic feasibility. J Environ Manage 272:111007. https://doi.org/10.1016/j.jenvman.2020.111007

Jose A, Macias V, Campos MC, Ana A (2021) Enhanced activated persulfate oxidation of ciprofloxacin using a low-quard titanium ore under sunlight: influence of the irradiation source on its transformation products. Environ Sci Pollut R:1-15. https://doi.org/10.1007/s11356-020-11564-8

Kang J, Duan X, Zhou L, Sun H, Tadé MO, Wang S (2016) Carbocatalytic activation of persulfate for removal of antibiotics in water solutions. Chem Eng J 288:399-405.

https://doi.org/10.1016/j.cej.2015.12.040

Karimipourfard D, Eslamloueyan R, Mehranbod N (2019) Novel heterogeneous degradation of mature landfill leachate using persulfate and magnetic $\mathrm{CuFe}_{2} \mathrm{O}_{4} / \mathrm{RGO}$ nanocatalyst. Process Saf Environ Prot 131:212-222. https://doi.org/10.1016/j.psep.2019.09.009

Lei Y, Chen CS, Tu YJ, Huang YH, Zhang H (2015) Heterogeneous degradation of organic pollutants by persulfate activated by $\mathrm{CuO}-\mathrm{Fe}_{3} \mathrm{O}_{4}$ : mechanism, stability, and effects of $\mathrm{pH}$ and bicarbonate ions. Environ Sci Technol 49:6838-6845. https://doi.org/10.1021/acs.est.5b00623

Li Z, Sun Y, Yang Y, Han Y, Wang T, Chen J, Tsang DCW (2020) Comparing biochar- and bentonitesupported Fe-based catalysts for selective degradation of antibiotics: mechanisms and pathway. Environ 
Res 183:109156. https://doi.org/10.1016/j.envres.2020.109156

Liu T, Wang L, Sun C, Liu X, Miao R, Lv Y (2019) A comparison of the photolytic and photocatalytic degradation of fluvastatin. Chem Eng J 358:1296-1304. https://doi.org/10.1016/j.cej.2018.10.107

Long A, Lei Y, Zhang H (2014) Degradation of toluene by a selective ferrous ion activated persulfate oxidation process. Ind Eng Chem Res 53:1033-1039. https://doi.org/10.1021/ie402633n

Lv J, Li YM (2018) Effect of ozonation on minocycline degradation and N-Nitrosodimethylamine formation. J Environ Sci Health A Tox Hazard Subst Environ Eng 53:617-628.

https://doi.org/10.1080/10934529.2018.1429724

Lv Y, Li Z, Zhou X, Cheng S, Zheng L (2020) Stabilization of source-separated urine by heat-activated peroxydisulfate. Sci Total Environ 749:142213. https://doi.org/10.1016/j.scitotenv.2020.142213

Maavia A, Aslam I, Tanveer M, Rizwan M, Iqbal MW, Tahir M, Hussain H, Boddula R, Yousuf M (2019) Facile synthesis of $\mathrm{g}-\mathrm{C}_{3} \mathrm{~N}_{4} / \mathrm{CdWO}_{4}$ with excellent photocatalytic performance for the degradation of Minocycline. Mater Sci Energy Technol 2:258-266. https://doi.org/10.1016/j.mset.2019.01.004

Mantzavinos D, Poulios I, Esplugas S, An T, Puma GL, Dionysiou DD (2017) Emerging advanced oxidation processes for the elimination of micro-pollutants. Chem Eng J 318:1-288.

https://doi.org/10.1016/j.cej.2017.03.053

Mossmann A, Dotto GL, Hotza D, Jahn SL, Foletto EL (2019) Preparation of polyethylene-supported zero-valent iron buoyant catalyst and its performance for Ponceau 4R decolorization by photo-Fenton process. J Environ Chem Eng 7:102963. https://doi.org/10.1016/j.jece.2019.102963

Neta P, Madhavan V, Zemel H, Fessenden RW (1977) Rate constants and mechanism of reaction of sulfate radical anion with aromatic compounds. J Am Chem Soc 99:163-164.

https://doi.org/10.1021/ja00443a030

Nie W, Mao Q, Ding Y, Hu Y, Tang H (2019) Highly efficient catalysis of chalcopyrite with surface bonded ferrous species for activation of peroxymonosulfate toward degradation of bisphenol A: a mechanism study. J Hazard Mater 364:59-68. https://doi.org/10.1016/j.jhazmat.2018.09.078

Niu CG, Wang Y, Zhang XG, Zeng GM, Huang DW, Ruan M, Li XW (2012) Decolorization of an azo dye orange $\mathrm{G}$ in microbial fuel cells using Fe(II)-EDTA catalyzed persulfate. Bioresour Technol 126:101-106. https://doi.org/10.1016/j.biortech.2012.09.001

Nowak M, Strzelczyk A, Reif PS, Schorlemmer K, Bauer S, Norwood BA, Oertel WH, Rosenow F, Strik H, Hamer HM (2012) Minocycline as potent anticonvulsant in a patient with astrocytoma and drug resistant epilepsy. Seizure 21:227-228. https://doi.org/10.1016/j.seizure.2011.12.009 
Qu GZ, Chu RJ, Wang H, Wang TC, Zhang ZQ, Qiang H, Liang DL, Hu SB (2020) Simultaneous removal of chromium $(\mathrm{VI})$ and tetracycline hydrochloride from simulated wastewater by nanoscale zero-valent iron/copper-activated persulfate. Environ Sci Pollut R 27:40826-40836. https://doi.org/10.1007/s11356020-10120-8

Rodriguez S, Santos A, Romero A (2011) Effectiveness of AOP's on abatement of emerging pollutants and their oxidation intermediates: nicotine removal with Fenton's Reagent. Desalination 280:108-113. https://doi.org/10.1016/j.desal.2011.06.055

Rodriguez S, Santos A, Romero A (2017) Oxidation of priority and emerging pollutants with persulfate activated by iron: effect of iron valence and particle size. Chem Eng J 318:197-205. https://doi.org/10.1016/j.cej.2016.06.057

Sabri M, Habibi-Yangjeh A, Vadivel S (2020) Novel $\mathrm{ZnO} / \mathrm{Ag}_{6} \mathrm{Si}_{2} \mathrm{O}_{7}$ nanocomposites for activation of persulfate ions in photocatalytic removal of organic contaminants under visible light. Mater Chem Phys 239:121988. https://doi.org/10.1016/j.matchemphys.2019.121988

Saien J, Soleymani AR, Sun JH (2011) Parametric optimization of individual and hybridized AOPs of $\mathrm{Fe}^{2+} / \mathrm{H}_{2} \mathrm{O}_{2}$ and $\mathrm{UV} / \mathrm{S}_{2} \mathrm{O}_{8}{ }^{2-}$ for rapid dye destruction in aqueous media. Desalination 279:298-305. https://doi.org/10.1016/j.desal.2011.06.024

Sharma A, Ahmad J, Flora SJS (2018) Application of advanced oxidation processes and toxicity assessment of transformation products. Environ Res 167:223-233.

https://doi.org/10.1016/j.envres.2018.07.010

Song Q, Feng Y, Liu G, Lv W (2019) Degradation of the flame retardant triphenyl phosphate by ferrous ionactivated hydrogen peroxide and persulfate: kinetics, pathways, and mechanisms. Chem Eng J 361:929936. https://doi.org/10.1016/j.cej.2018.12.140

Taha SM, Amer ME, Elmarsafy AM, Elkady MY, Chovelon JM (2016) Degradation of boscalid by nitrogendoped/undoped $\mathrm{TiO}_{2}$ and persulfate ions using different activation conditions and the identification of its main degradation products using LC/MS/MS. Chem Eng J 288:845-857. https://doi.org/10.1016/j.cej.2015.12.053

Teel AL, Ahmad M, Watts RJ (2011) Persulfate activation by naturally occurring trace minerals. J Hazard Mater 196:153-159. https://doi.org/10.1016/j.jhazmat.2011.09.011

Torres-Blancas T, Roa-Morales G, Ureña-Núñez F, Barrera-Díaz C, Dorazco-González A, Natividad R (2017) Ozonation enhancement by Fe-Cu biometallic particles. J Taiwan Inst Chem Eng 74:225-232. https://doi.org/10.1016/j.jtice.2017.02.025

Wang Q, Wang B, Ma Y, Xing S (2018) Enhanced superoxide radical production for ofloxacin removal via persulfate activation with Cu-Fe oxide. Chem Eng J 354:473-480. 
Wang S, Wang J (2018) Radiation-induced degradation of sulfamethoxazole in the presence of various inorganic anions. Chem Eng J 351:688-696. https://doi.org/10.1016/j.cej.2018.06.137

Wang S, Wu J, Lu X, Xu W, Gong Q, Ding J, Dan B, Xie P (2019) Removal of acetaminophen in the $\mathrm{Fe}^{2+} /$ persulfate system: kinetic model and degradation pathways. Chem Eng J 358:1091-1100. https://doi.org/10.1016/j.cej.2018.09.145

Wang X, Wang L, Li J, Qiu J, Cai C, Zhang H (2014) Degradation of acid orange 7 by persulfate activated with zero valent iron in the presence of ultrasonic irradiation. Sep Purif Technol 122:41-46. https://doi.org/10.1016/j.seppur.2013.10.037

Wu H, Xu X, Shi L, Yin Y, Sun H (2019) Manganese oxide integrated catalytic ceramic membrane for degradation of organic pollutants using sulfate radicals. Water Res 167:115110. https://doi.org/10.1016/j.watres.2019.115110

Xing B, Dong J, Yang G, Jiang N, Liu X, Yuan J (2020) An insight into N,S-codoped activated carbon for the catalytic persulfate oxidation of organic pollutions in water: effect of surface functionalization. Appl Catal A Gen 602:117714. https://doi.org/10.1016/j.apcata.2020.117714

Xu X, Chen J, Qu R, Wang Z (2017) Oxidation of Tris (2-chloroethyl) phosphate in aqueous solution by UVactivated peroxymonosulfate: kinetics, water matrix effects, degradation products and reaction pathways. Chemosphere 185:833-843. https://doi.org/10.1016/j.chemosphere.2017.07.090

Yang Q, Ma Y, Chen F, Yao F, Sun J, Wang S, Yi K, Hou L, Li X, Wang D (2019) Recent advances in photoactivated sulfate radical-advanced oxidation process (SR-AOP) for refractory organic pollutants removal in water. Chem Eng J 378:122149. https://doi.org/10.1016/j.cej.2019.122149

Yang S, Wang P, Yang X, Shan L, Zhang W, Shao X, Niu R (2010) Degradation efficiencies of azo dye acid orange 7 by the interaction of heat, UV and anions with common oxidants: persulfate, peroxymonosulfate and hydrogen peroxide. J Hazard Mater 179:552-558. https://doi.org/10.1016/j.jhazmat.2010.03.039

Yao C, Zhang Y, Du M, Du X, Huang S (2019) Insights into the mechanism of non-radical activation of persulfate via activated carbon for the degradation of p-chloroaniline. Chem Eng J 362:262-268. https://doi.org/10.1016/j.cej.2019.01.040

Yao X, Lin Q, Zeng L, Xiang J, Yin G, Liu Q (2017) Degradation of humic acid using hydrogen peroxide activated by $\mathrm{CuO}-\mathrm{CO}_{3} \mathrm{O}_{4} @ \mathrm{AC}$ under microwave irradiation. Chem Eng J 330:783-791. https://doi.org/10.1016/j.cej.2017.08.008

Zhang R, Yang Y, Huang $\mathrm{CH}$, Li N, Liu H, Zhao L, Sun $\mathrm{P}$ (2016) UV/ $\mathrm{H}_{2} \mathrm{O}_{2}$ and UV/PDS treatment of trimethoprim and sulfamethoxazole in synthetic human urine: transformation products and toxicity. 
Zhang X, Deng H, Zhang G, Yang F, Yuan GE (2020) Natural bornite as an efficient and cost-effective persulfate activator for degradation of tetracycline: performance and mechanism. Chem Eng $\mathrm{J}$ 381:122717. https://doi.org/10.1016/j.cej.2019.122717

\section{Figures}
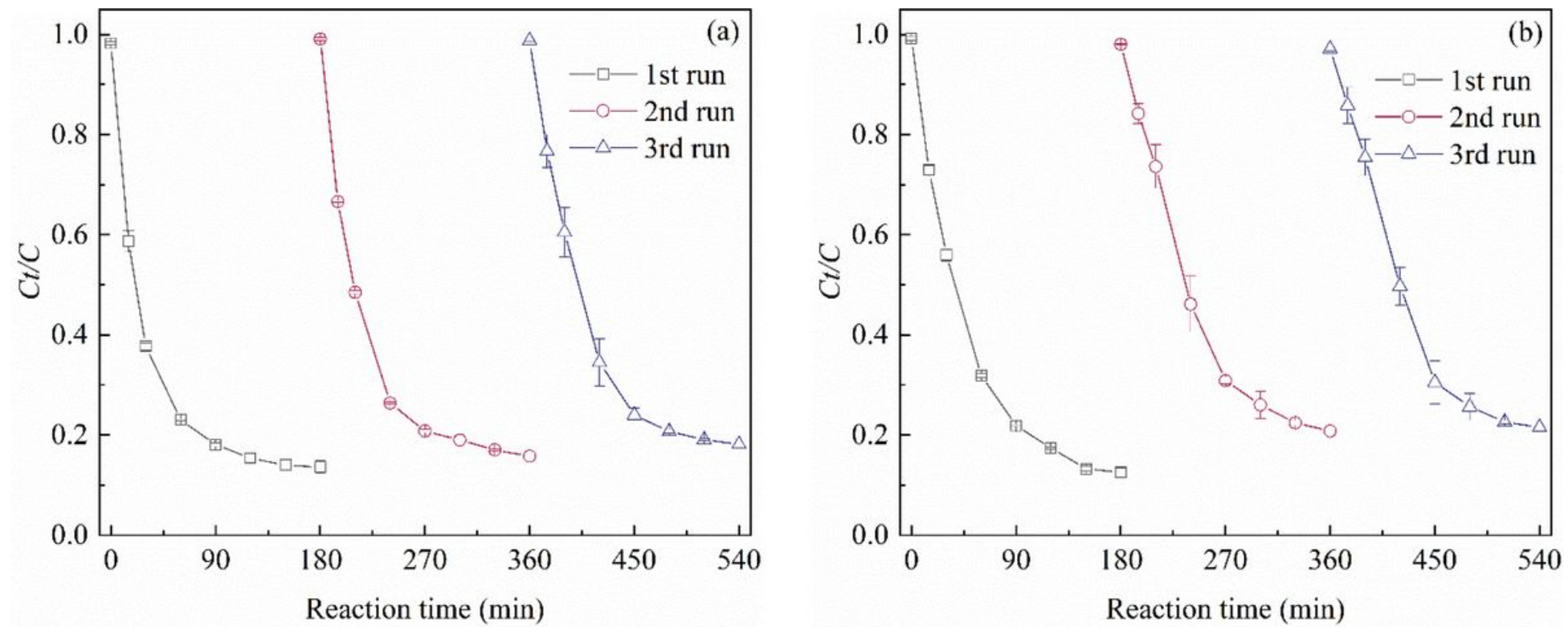

Figure 1

Effect of oxidant concentration $(\mathrm{a}, \mathrm{b})$ and NBo dosage on MNC degradation by NBo/PS and NBo/H2O2 processes. Experiment conditions: $[\mathrm{MNC}] 0=10 \mathrm{mg} / \mathrm{L}, \mathrm{pH}=4.5 \pm 0.3$. [NBo]0 $=0.15 \mathrm{~g} / \mathrm{L},[\mathrm{H} 2 \mathrm{O} 2] 0=[\mathrm{PS}] 0=0-$ 1000uM in (a, b); [H2O2]0=[PS]0=500uM, [NBo]0=0-0.2g/L in (c, d)
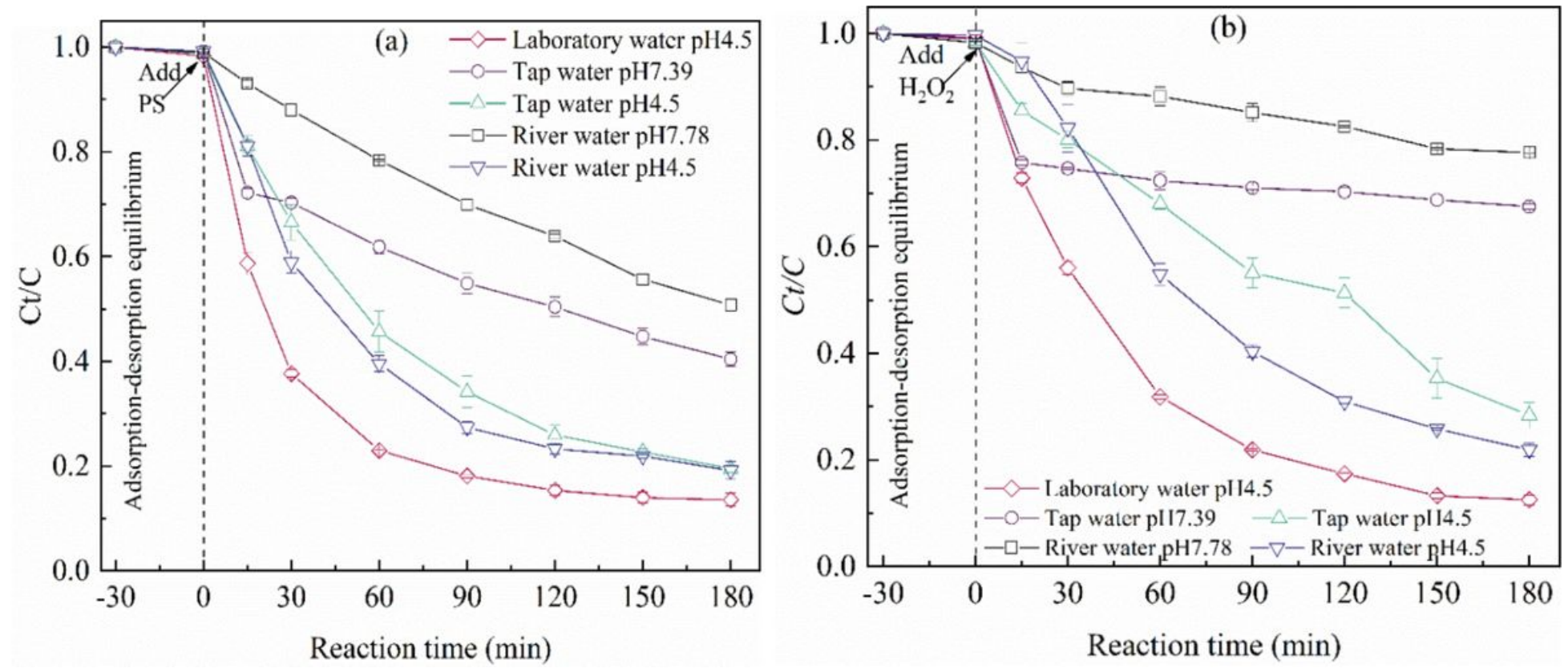
Figure 2

Effect of common inorganic anions $(a, b)$ and $\mathrm{pH}(\mathrm{c})$ on the degradation of MNC in the NBo/PS and $\mathrm{NBo} / \mathrm{H} 2 \mathrm{O} 2$ processes. Experiment conditions: $[\mathrm{MNC}] 0=10 \mathrm{mg} / \mathrm{L},[\mathrm{H} 2 \mathrm{O} 2] 0=[\mathrm{PS}] 0=500 \mathrm{uM},[\mathrm{NBo}] 0=0.15 \mathrm{~g} / \mathrm{L}$. $\mathrm{pH}=4.5 \pm 0.3$ in $(\mathrm{a}, \mathrm{b})$ and $\mathrm{pH}=2.5-9.5$ in (c)
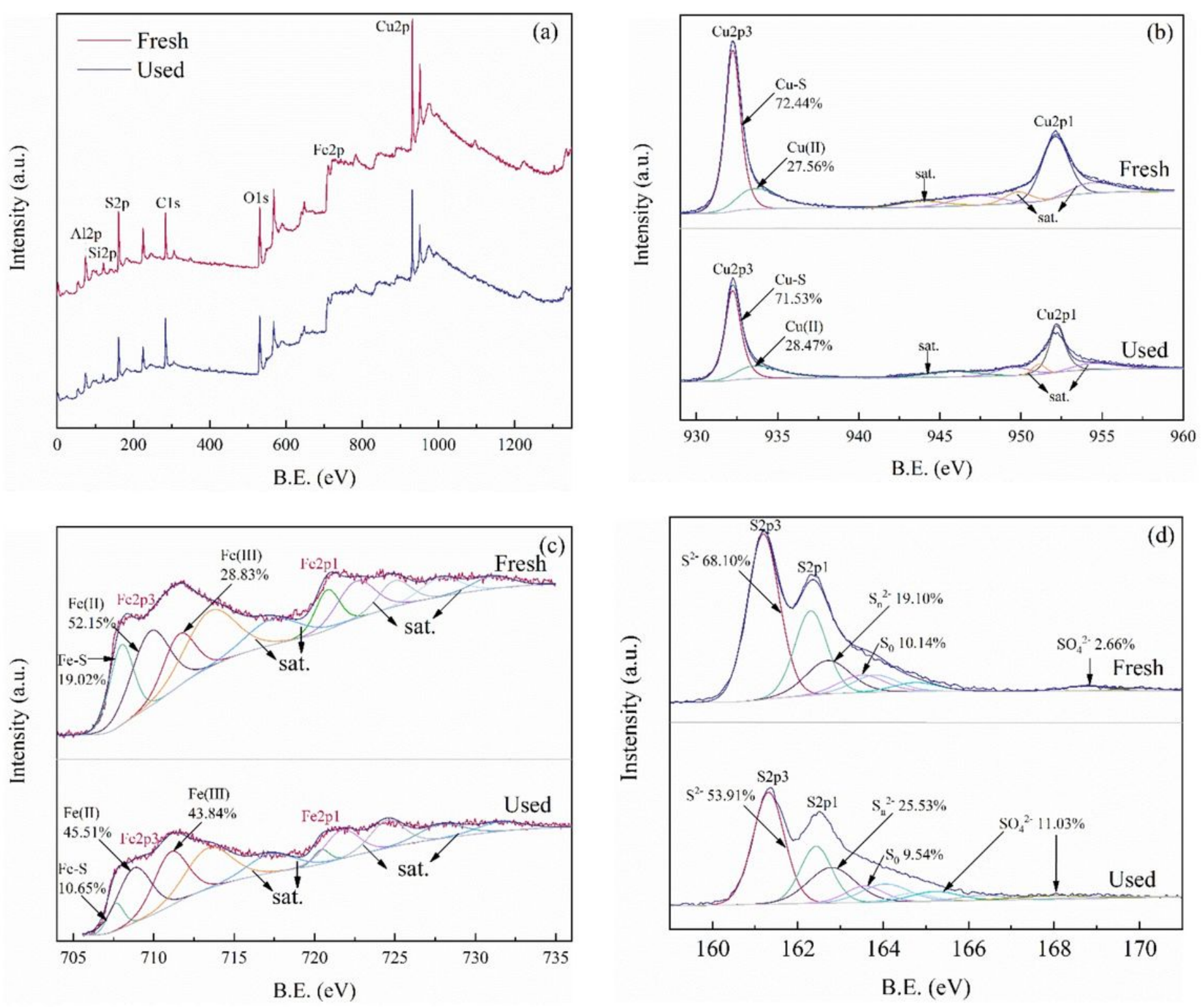

Figure 3

The effect of the presence of free radical quenchers EtOH and TBA on MNC degradation in the NBo/PS (a) and $\mathrm{NBo} / \mathrm{H} 2 \mathrm{O} 2$ (b) processes. EPR spectra of hydroxyl and sulfate radicals captured by DMPO in the (c) $\mathrm{NBo} / \mathrm{PS}$ and (d) NBo/H2O2 processes. Experiment conditions: [MNC]0 $=10 \mathrm{mg} / \mathrm{L}, \mathrm{pH}=4.5 \pm 0.3$, $[\mathrm{H} 2 \mathrm{O} 2] 0=[\mathrm{PS}] 0=500 \mathrm{uM},[\mathrm{NBO}] 0=0.15 \mathrm{~g} / \mathrm{L}$ 

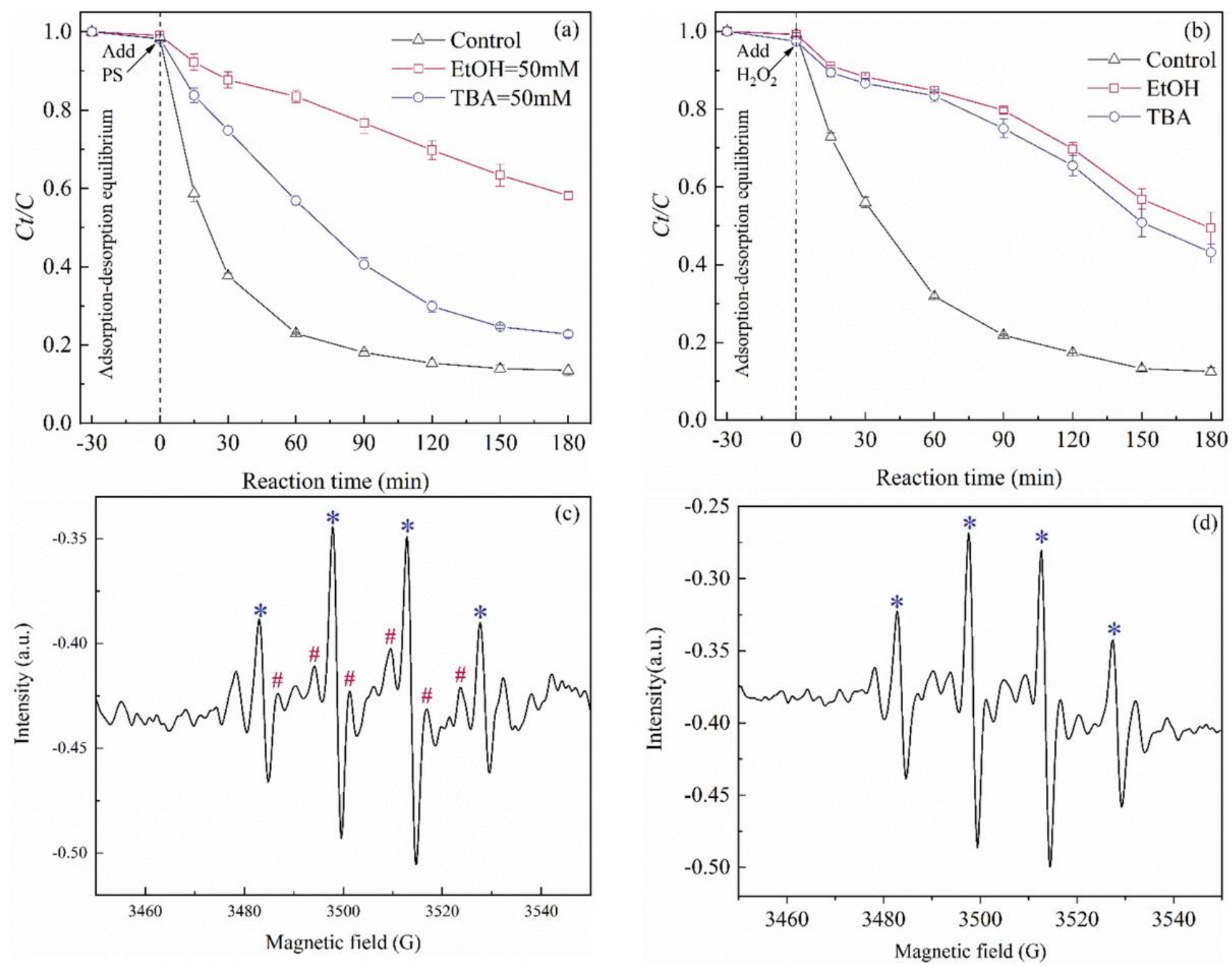

Figure 4

XPS spectra of fresh and used NBo: (a) survey spectra; (b) high-resolution Cu 2p; (c) high-resolution Fe $2 p ;$ (d) high-resolution $S 2 p$ 

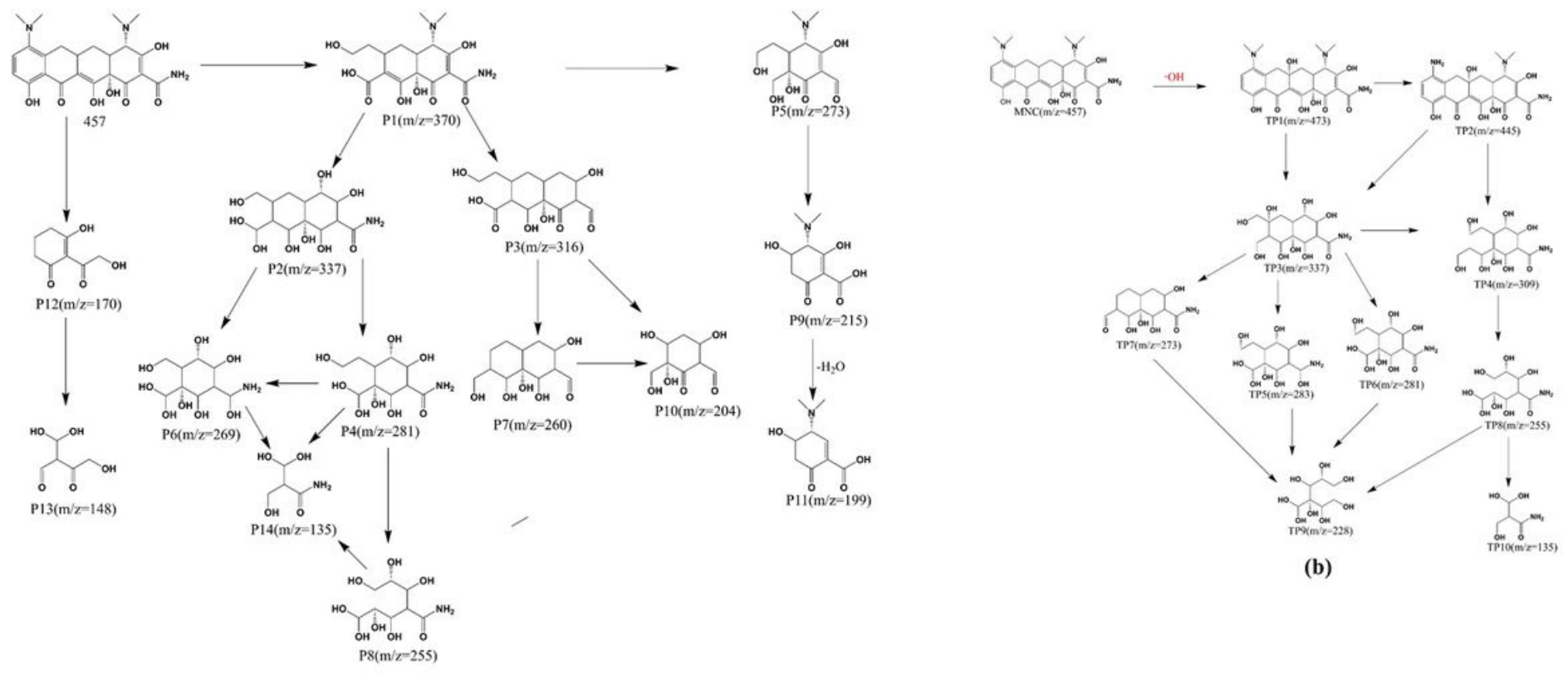

(b)

(a)

\section{Figure 5}

Products and pseudotransformation pathway of MNC degradation by the NBo/PS and NBo/H2O2 processes
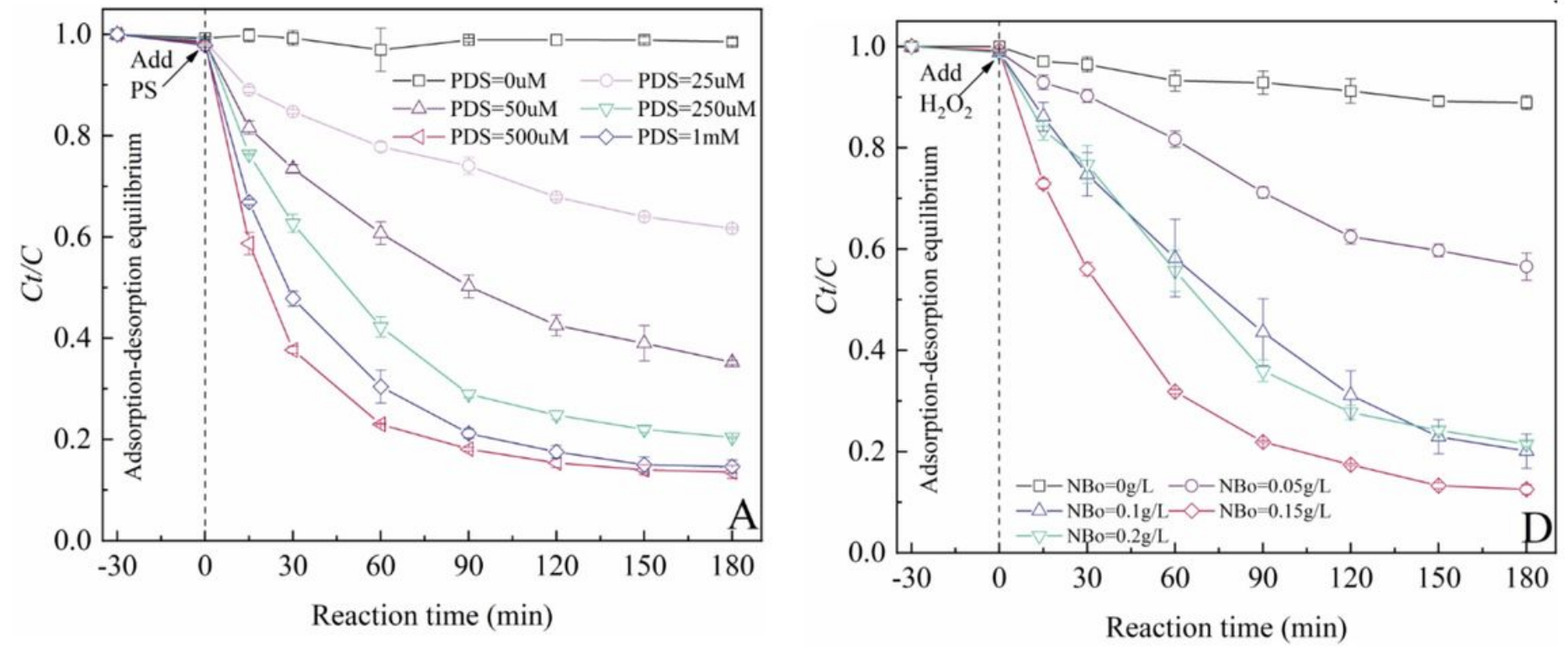

Figure 6

Degradation of MNC in different aqueous media by NBo/PS (a) and NBo/H2O2 (b) processes. Experiment conditions: [MNC]0 $=10 \mathrm{mg} / \mathrm{L}, \mathrm{pH}=4.5 \pm 0.3,[\mathrm{H} 2 \mathrm{O} 2] 0=[\mathrm{PS}] 0=500 \mathrm{uM},[\mathrm{NBo}] 0=0.15 \mathrm{~g} / \mathrm{L}$ 

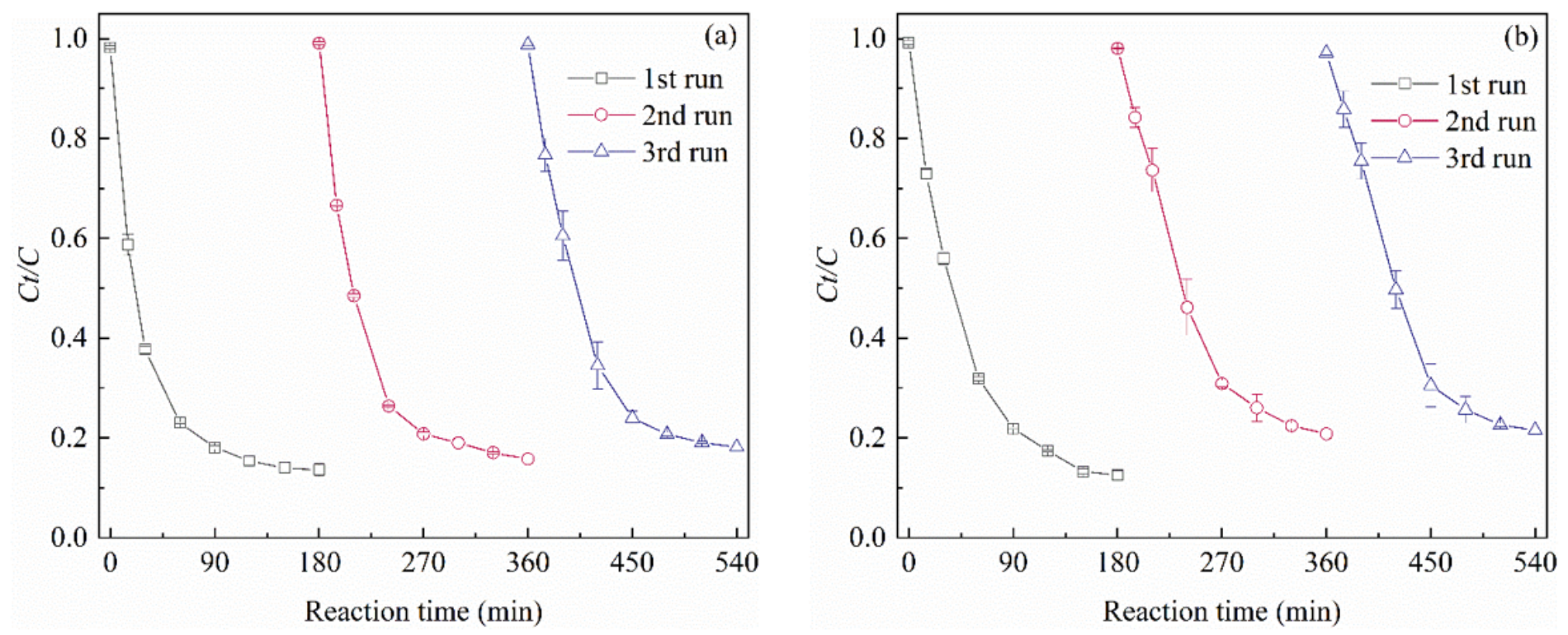

Figure 7

Activated performance of NBo reused in NBo/PS (a) and NBo/H2O2 (b) processes. Experiment conditions: $[\mathrm{MNC}] 0=10 \mathrm{mg} / \mathrm{L}, \mathrm{pH}=4.5 \pm 0.3,[\mathrm{PS}] 0=500 \mathrm{uM},[\mathrm{NBo}] 0=0.15 \mathrm{~g} / \mathrm{L}$ 


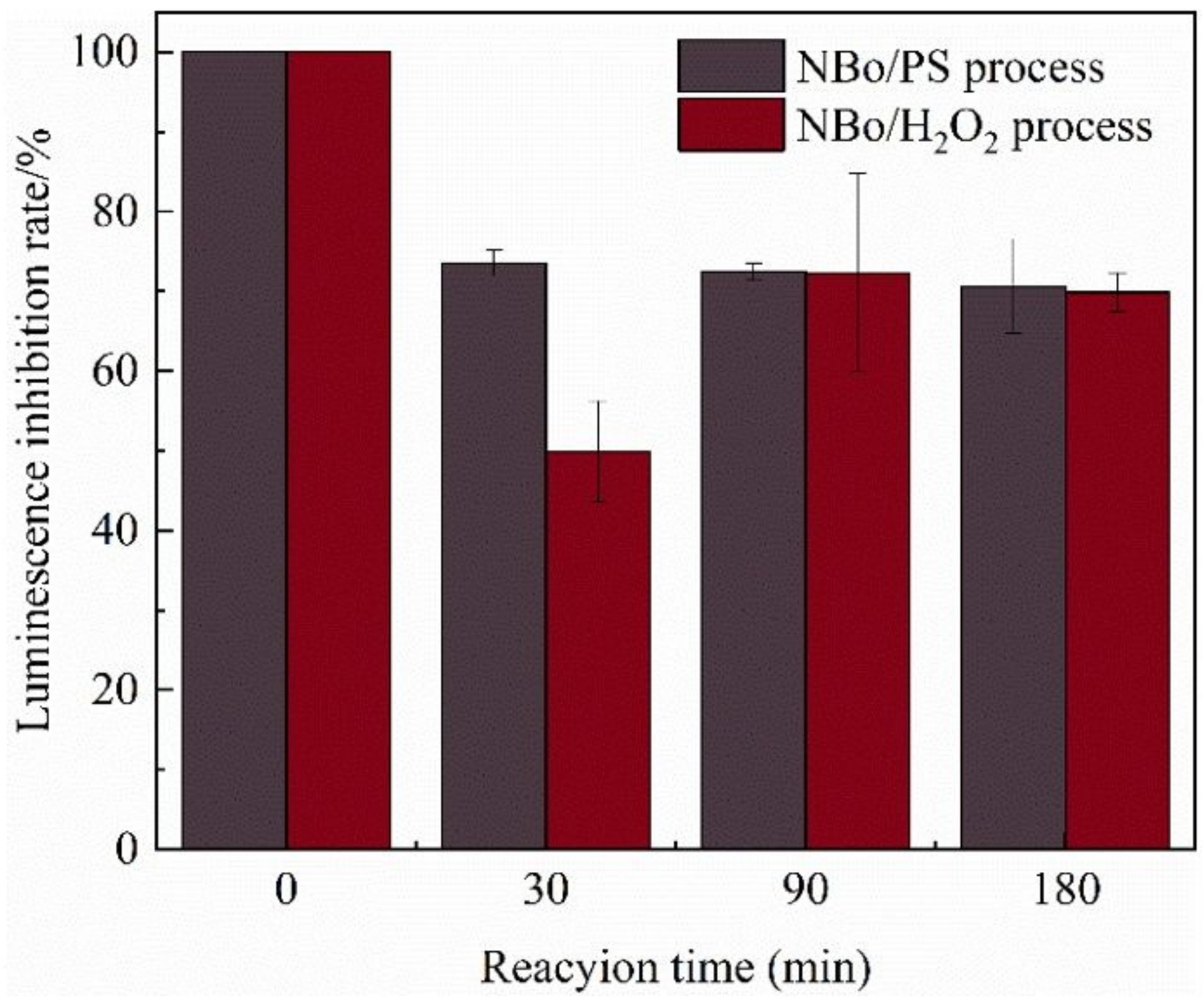

Figure 8

Luminescence inhibition rate of MNCs in the NBo/PS and NBo/H2O2 processes. Experiment conditions: $[\mathrm{MNC}] 0=10 \mathrm{mg} / \mathrm{L}, \mathrm{pH}=4.5 \pm 0.3,[\mathrm{H} 2 \mathrm{O} 2] 0=[\mathrm{PS}] 0=500 \mathrm{uM},[\mathrm{NBo}] 0=0.15 \mathrm{~g} / \mathrm{L}$

\section{Supplementary Files}

This is a list of supplementary files associated with this preprint. Click to download.

- renamedab3c4.docx 